\title{
Competitors' Strategic Heterogeneity and Firm Performance
}

\author{
Jaime Gómez, Raquel Orcos, Sergio Palomas
}

\begin{abstract}
This paper explores intra-industry heterogeneity by proposing a new perspective. Whereas the strategic management literature tends to conceptualize strategic heterogeneity as the divergence between a focal firm and its rivals, we offer a complementary view in which we consider it to be the result of the differences among the strategic positions of the rivals of a firm. We argue that, when heterogeneity is examined from this perspective, vicarious learning and competitive alignment (instead of competition, collusion or legitimation) are the mechanisms that explain the impact of heterogeneity on performance. We also propose that the experience that firms accumulate by competing with the same rivals moderates this relationship. We test our hypotheses on the Spanish banking sector over the period 1999-2009. The results are consistent with them.
\end{abstract}

(c) 2014 Elsevier Ltd. All rights reserved.

\section{Introduction}

The traditional concern of strategic management with the differences in performance among the firms that populate an industry has led researchers to focus on firm heterogeneity as a cornerstone in the analysis of competitive advantage (Barney, 1991; Peteraf, 1993; Scherer and Ross, 1990). From a strategic management perspective, heterogeneity tends to be conceptualized as a characteristic of the firm in relation to its rivals (i.e., how different a firm is compared to its direct competitors). In contrast, in this article we maintain that heterogeneity can be conceptualized in other ways. We propose that heterogeneity can also be understood as a property of the set of direct competitors of a focal firm (i.e., how different the competitors of a focal firm are from each other). Thus, while the traditional approach to heterogeneity conceives heterogeneity as the strategic distance between the focal firm and its direct rivals (Caves and Porter, 1977; McGee and Thomas, 1992; Peteraf, 1993), our conception focuses on the heterogeneity stemming from the strategic distances among the direct rivals of the focal firm.

Our contention is that the degree of strategic heterogeneity among rivals determines both the amount of information available from the observation of the strategies of rivals and the difficulties in designing effective competitive strategies. As a consequence, we propose vicarious learning and competitive alignment as the most appropriate mechanisms to clarify the impact of heterogeneity in the set of competitors on firm performance. We argue that both learning through observation and competitive alignment are conditioned by the plurality of strategies that the rivals adopt. On the one hand, the strategic heterogeneity in the set of competitors determines the quality and quantity of knowledge that can be learnt from them (Haunschild and Sullivan, 2002; Barnett, 2008). A high level of strategic heterogeneity in the group of rivals offers greater opportunities for acquiring knowledge through observation. On the other hand, heterogeneity also makes it more difficult for the firm to find a strategic configuration that aligns with the strategies of all its rivals (Ghemawat, 1991; Barnett and Hansen, 1996). The combination of these two effects results in an inverted U relationship between strategic heterogeneity in the set of competitors and focal firm performance.

This paper also analyzes how the experience accumulated with rivals conditions the impact of strategic heterogeneity among competitors on performance. Firms can gather information about the strategic options of their rivals by observing them or by retrieving past observations from the organizational memory (Huber, 1991). As firms accumulate competitive experience, they have greater knowledge about the strategic positions of the rivals and, as a result, the need to observe their rivals to obtain information about different strategic options decreases. We argue that, in these cases, competitive experience replaces strategic heterogeneity in the set of rivals as a source of learning for reasons based on information preference, information redundancy and information costs (Schwab, 2007). Consequently, basing our arguments on a learning perspective, we argue that competitive experience negatively moderates the link between the strategic heterogeneity of the set of rivals and firm performance. 
The addition of this approach to the analysis of strategic heterogeneity has two benefits. First, it complements the traditional perspective. By focusing on the position of the firm in relation to its competitors, the traditional approach said nothing about whether these rivals were a relatively homogeneous or heterogeneous group. This may be seen as a gap in the theory because, irrespective of the strategic position of a firm, rivals can show disparate levels of strategic heterogeneity. As we show in this article, this characteristic of rivals influences the results of the firm. Consequently, the proposed approach complements the traditional one and analyzes the consequences of strategic heterogeneity within an industry more comprehensively.

Second, the new approach incorporates theoretical mechanisms that help us to understand the effect of strategic diversity on firm performance. The traditional view argues in terms of legitimation, collusion and competitive behaviour to explain the consequences of the strategic distance between the firm and its rivals (Cool and Dierickx, 1993; Deephouse, 1999; Fiegenbaum and Thomas, 1990; Gimeno and Woo, 1996; Meyer and Rowan, 1977; Peteraf and Shanley, 1997). However, these arguments are not well suited to the analysis of the strategic heterogeneity among competitors, as they are based on the focal firm and its location in the strategic space. As we argue in this article, the mechanisms that explain the role of strategic heterogeneity as a characteristic of the set of rivals are vicarious learning and competitive alignment. Consequently, this new perspective not only complements, but also expands the analysis of strategic heterogeneity and its implications on firm performance.

We test our hypotheses in the Spanish retail banking sector between 1999 and 2009. Like many other banking sectors in the world, it underwent a deregulation process in the '80s and '90s of the past century which reduced the restrictions on the activities that each kind of bank (commercial banks, saving banks and credit unions) was allowed to perform. As a result, many different strategic orientations developed and the competitive patterns changed greatly. In the period analyzed, the Spanish banking sector is a context in which we can take advantage of varying levels of heterogeneity to test our model.

Our results confirm that strategic heterogeneity in the set of rivals influences focal firm performance in the form of an inverted U. This means that firms whose direct rivals show an intermediate level of strategic heterogeneity will perform better than firms operating in contexts of high or low levels of strategic heterogeneity. Our arguments, based on vicarious learning and competitive alignment, expand our knowledge about intra-industry heterogeneity. Our findings also suggest that competitive experience with the same rivals reduces the impact of strategic heterogeneity on firm performance. This is an important contribution to the organizational learning literature because it suggests that a firm's competitive experience and the strategic heterogeneity in its set of rivals can be considered alternative sources of information.

The rest of the paper is structured as follows. First, we offer a brief overview of the previous conceptualization of strategic heterogeneity and the mechanisms through which it influences firm performance. In addition, we explain the suitability of vicarious learning and competitive alignment to explore the impact of strategic heterogeneity in the set of rivals on firm performance. Then, we develop our hypotheses about heterogeneity in the set of rivals and competitive experience. The fourth Section describes the context in which we test these hypotheses, a representative sample of the Spanish retail banking sector, and the fifth Section presents the results. Finally, the last Section concludes and discusses the main implications.

\section{Theoretical framework}

Our theoretical framework briefly describes the traditional approximations to the study of strategic heterogeneity and the new perspective that is proposed in this paper. First, we review the main mechanisms used in strategic management to analyze the consequences of heterogeneity when it is conceptualized as the strategic distance between the focal firm and its rivals. Second, we present vicarious learning and competitive alignment as the mechanisms explaining the effect of heterogeneity when it is analyzed from our perspective: strategic distance among rivals.

\section{The traditional approach: the analysis of similarity between a firm and its competitors}

The strategic heterogeneity between a focal firm and its rivals has received a great deal of attention in strategic management (Deephouse, 1999; Porter, 1980). Many strategy scholars have tried to determine the value of being different and the value of being the same, given that this is important for managers as they try to achieve the right market position for their firms. In spite of the efforts of researchers, there is still no agreement on the balance between similarity and differentiation that firms should choose. The literature is divided between those who recommend occupying close positions to competitors and those who are in favor of occupying distant ones. This lack of agreement may be due to the plurality of arguments used to explain the effect of the strategic heterogeneity between a firm and its competitors on performance. Among these arguments, those based on competition, legitimation and collusion are the most popular in the strategic management field (Barney, 1991; Baum and Mezias, 1992; Caves and Porter, 1977; DiMaggio and Powell, 1983; Meyer and Rowan, 1977). These mechanisms use different suppositions and provide different predictions about the role of heterogeneity in competitive dynamics and performance.

According to the competition mechanism, the distance between market positions reduces competitive intensity and, therefore, improves firm performance. This mechanism considers that markets have finite resources that are divided among competing firms according to their positions. Firms occupying the same position in the market depend on similar resources to develop their activities and, as a consequence, compete more intensively among themselves (Audia and Kurkoski, 2012; 
Barney, 1991; Hannan and Freeman, 1977, 1989). Conversely, firms that adopt a distinct position are able to earn higher rents by avoiding direct competition for resources (Baum and Mezías, 1992; Porter, 1980, 1991).

The legitimation mechanism presumes that the organizational field legitimates a limited number of strategies or organizational templates. Adopting one of these templates provides legitimacy and institutional support, which secures the flow of certain resources, reduces uncertainty and enhances survival. As firms try to conform to these templates, they become more similar (Aldrich and Fiol, 1994; Ashforth and Gibbs, 1990; DiMaggio and Powell, 1983). In contrast, firms that select a strategy which differs from these templates lose legitimacy and experience difficulties to acquire resources (Ashforth and Gibbs, 1990; Suchman, 1995). Thus, the legitimation mechanism assumes that similarity among firms adopting these templates confers legitimacy and improves firm performance.

Finally, the collusion mechanism proposes that similar firms tend to compete less aggressively among themselves. This reduction in rivalry is mainly explained by two processes. First, similarity leads firms to recognize competitive interdependences and increases familiarity (Caves and Porter, 1977). Similar firms are more likely to correctly understand the decisions taken by the others and anticipate their moves more accurately. This makes tacit collusion easier and generates incentives to forbear (Peteraf, 1993; Porter, 1979). Second, similar firms are likely to use the same resources and capabilities, which increases their capability of retaliation against each other (Chen, 1996; Fuentelsaz and Gómez, 2006). When the retaliatory capability of rivals is high, initiating any exchange of competitive moves makes less sense and collusion with these rivals becomes more attractive.

While the competition mechanism considers that similarity in market positions negatively influences firm performance, the legitimation and collusion mechanisms sustain that the effect of similarity is positive (Caves and Porter, 1977; Chen and Hambrick, 1995; Miller and Chen, 1995; Porter, 1980, 1991). These three mechanisms are valid to analyze heterogeneity when it is conceived as the distance between the market positions of a focal firm and its rivals, given that all three base their arguments on the similarity or divergence between the focal firms and its rivals. However, when heterogeneity is conceptualized as the level of dispersion of competitors' strategies, these arguments are not valid. As we will explain in the next section, vicarious learning and competitive alignment are the mechanisms that better explain the impact of our complementary conception of heterogeneity.

Heterogeneity in the set of competitors: similarity or divergence among direct rivals of the focal firm

Figure 1 graphically depicts the traditional approach and our proposal to exploring the impact of strategic heterogeneity. While strategy scholars examine heterogeneity by focusing on the similarity or divergence between a focal firm and its rivals, this article considers the heterogeneity that comes from strategic diversity in the group of direct competitors. By strategic heterogeneity in the set of rivals we refer to the extent of variation in the strategic positions of the direct rivals of the focal firm. Although many attributes of the firm could be analyzed to explore this variation, we focus on firm strategy, which is conceptualized as the position of the firm in the competitive market (Porter, 1980).

The mechanisms reviewed in the previous section cannot be applied to the analysis of the effects of the strategic diversity of the set of rivals. The competition mechanism is determined by the extent to which the resource requirements of a focal firm overlap with the resource needs of its rivals. The degree to which a focal firm competes with other firms for the same resources can only be determined by examining a focal firm's market position with respect to the market positions of its rivals. Similarly, the legitimacy mechanism requires an understanding of the position of a firm with respect to its rivals to analyze the way in which the focal firm resembles other firms as it adopts the established institutional practice. Valuing the extent to which firms obtain legitimacy by converging towards some institutional templates involves considering the market position of the focal firm with respect to that of its rivals. Given that we focus on similarity or divergence among rivals, the legitimation mechanism is not appropriate either. Finally, the collusion mechanism also requires comparing the market position of the focal firm and its rivals. Similarity or divergence between firms determines the incentives to collude and cooperate because it conditions the recognition of the competitive interdependences and of the retaliation capability of firms. Therefore, we also exclude the collusion mechanism as an argument that can explain the influence of heterogeneity among rivals on firm performance.

We propose that the mechanisms that best explain the link between our conception of heterogeneity and firm performance are vicarious learning and competitive alignment. Both these mechanisms are directly influenced by the degree of heterogeneity in the set of competitors. The variation in the strategies of rivals determines the number of strategic options from which the focal firm can learn through observation and to which it may need to adjust. High levels of strategic heterogeneity in the set of rivals mean a greater possibility of gathering information about different strategic positions but, also, more complexity in the achievement of competitive alignment. Thus, the strategic heterogeneity in the set of rivals simultaneously conditions the ability of the firm to learn vicariously and to adjust to its local competitive environment. Next, we offer a brief conceptualization of our explanatory mechanisms: vicarious learning and competitive alignment.

Vicarious learning is a specific form of organizational learning (Argote and Miron-Spektor, 2011). In spite of the importance of organizational learning, the literature lacks an unanimous definition of the concept. Our approximation is based on the perspective described by Huber (1991). We consider that a firm learns if, after processing information, the range of its potential behaviors or actions is modified. This perspective assumes that learning involves acquiring information and transforming it into knowledge, regardless of whether this knowledge is eventually applied to change behaviour. As a 
a

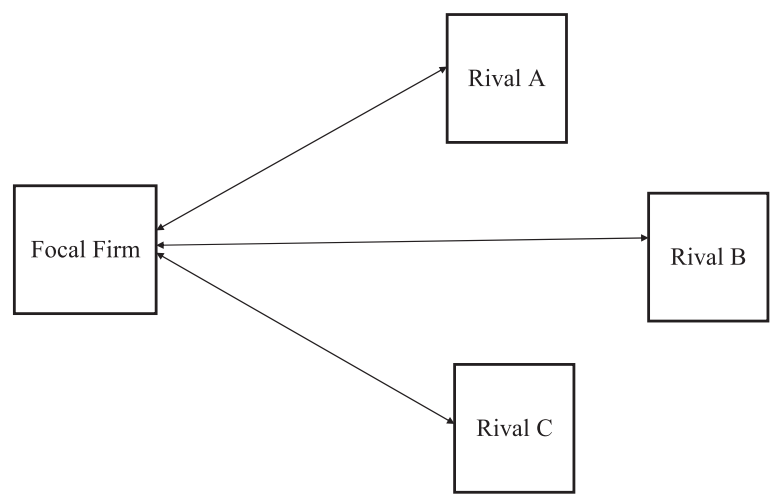

b

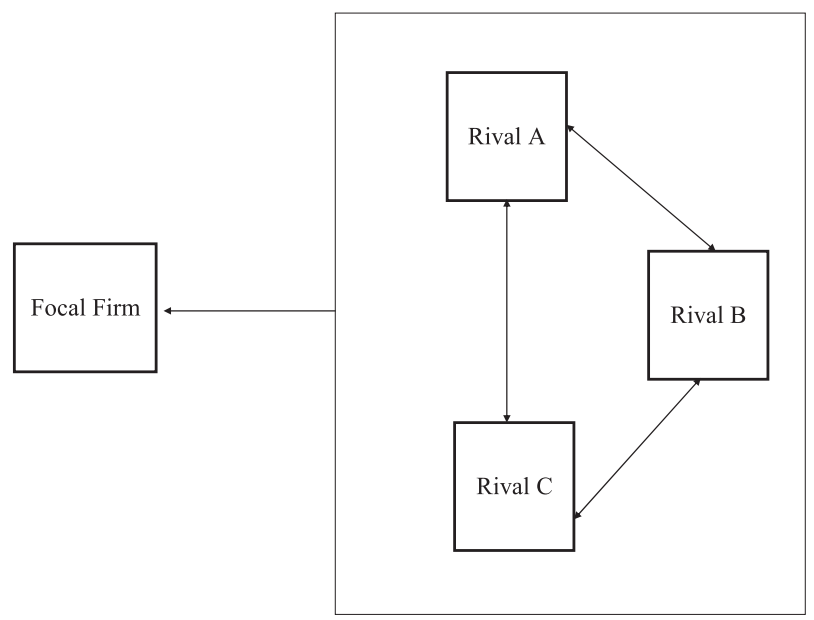

Figure 1. (a) The traditional approach to heterogeneity. Strategic distance between the focal firm and its rivals. (b) A complementary approach to heterogeneity. Strategic distances among rivals of the focal firm

consequence, in our framework, organizational learning and adaptation are different processes. First, firms learn, and then if it is necessary they modify their conduct according to what they have previously learnt.

The first step in organizational learning is to gather information. Firms can obtain information from different sources including their own experience, direct communication with other organizations, and observation (Huber, 1991; Lieberman and Asaba, 2006). As mentioned above, this paper focuses on vicarious learning, which is a process in which firms obtain information from the behaviors observed in other firms. We focus our attention on vicarious learning because of the implications that strategic heterogeneity in the set of rivals has on the result of the observation process. If the diversity in the market positions of direct competitors is high, the focal firm can observe different strategies that are suitable to this specific context. Conversely, if rivals are homogenous in terms of their market positions, the possibility of learning alternative courses of action through observation is lower.

We focus on vicarious learning from direct competitors because they are usually the primary reference points of observation. Direct rivals experience similar environments, opportunities and threats (Greve, 2000). As a result, their observation offers accurate information on the outcome of different strategies, reducing search, experimentation or implementation costs (Bikhchandani et al., 1998). This means that, through learning vicariously from competitors, the firm learns about alternative courses of action that may be taken to seize opportunities and to respond to threats (Peteraf and Shanley, 1997). In other words, observation helps the firm to take advantage of opportunities and reduces the risk of committing strategic mistakes (Kim and Miner, 2007). As a result, vicarious learning from direct rivals should have a positive impact on firm performance.

The second mechanism that explains firm heterogeneity from our perspective is competitive alignment. The concept of “alignment", rooted in population ecology and contingency theory (Hannan and Freeman, 1977), has occupied a central role in organization theory and strategic management (Venkatraman and Camillus, 1984). The term "alignment" refers to "matching" or "congruence". It is commonly held that firms, in order to perform adequately, have to achieve alignment with both their external and internal environments (Filatochev and Nakajima, 2010; Miller, 1992; Siggelkow, 2001). Internal alignment means coherence among structure, strategy and processes, while external alignment refers to the match between the environment and the organization (Siggelkow, 2001). Given that we analyze the consequences of strategic heterogeneity in the environment, our focus is on external alignment. 
External alignment reflects the appropriateness of the configuration of activities to the environmental conditions faced by the firm. External alignment involves two kinds of adjustments. First, firms have to adapt to their general environment (Bourgeois, 1980), which encompasses social, political and macroeconomic dimensions. Second, they have to achieve congruence with their local environments, which includes factors such as the actions of their competitors, the preferences of their customers and the available technology (Jaworski and Kohli, 1993; Siggelkow, 2001).

We focus on a particular type of external alignment, that which takes place with direct competitors (Zajac et al., 2000). We refer to adjustment with direct rivals as competitive alignment. Firms that enjoy a high degree of competitive alignment are more likely to survive the competitive actions of their rivals because they are capable of developing effective reactions. On the contrary, in the absence of competitive alignment, the responses of firms are slower and less effective. As a consequence, the lack of competitive alignment may have a negative effect on the performance of the firm. We consider that strategic heterogeneity in the set of rivals conditions the capacity of the firm to find a position that matches the positions of its competitors. The higher the diversity in the group of rivals, the more heterogeneous the competitive actions that the firm will have to confront and the more difficult it will be for the firm to develop effective responses that protect its market position.

\section{Hypotheses}

In this section, we take vicarious learning and competitive alignment into consideration to predict the relationship between strategic heterogeneity in the set of rivals and focal firm performance. We suggest that this relationship adopts an inverted $U$ shape. After that, we argue that the effect of strategic heterogeneity changes as firms accumulate competitive experience with the same rivals. Specifically, we propose that competitive experience reduces the impact of strategic heterogeneity in the set of rivals on firm performance. We explain this negative moderation by arguing that competitive experience substitutes the observation of current rivals as a source of learning.

\section{Strategic heterogeneity in the set of rivals and focal firm performance}

\section{Vicarious learning and strategic heterogeneity}

The amount of knowledge that can be acquired through vicarious learning depends on the variety of strategic orientations developed by rivals. In heterogeneous contexts, the firm has a higher probability of observing novel strategic options and, in turn, of learning suitable reactions to a greater number of contingencies. Firms that have a heterogeneous group of rivals receive richer lessons about the competitive logic of their context (Barnett, 2008) and develop richer structures of knowledge (Vermeulen and Barkema, 2001). Furthermore, given the wider set of strategic options considered, they have a lower probability of systematically reproducing previous behaviors and of falling into competency traps (Levinthal and March, 1993).

The quality of acquired knowledge is also affected by the extent of strategic heterogeneity among rivals. Heterogeneity helps to clarify latent causes and results in a deeper understanding of the problem at hand (Haunschild and Sullivan, 2002). If every rival follows a similar strategy, the firm may accept the observed strategy as adequate, without further inquiry. However, if many different strategies are implemented in the industry, the focal firm has to develop a more detailed observation process to determine the best alternative. Consequently, strategic heterogeneity improves both the quantity and the quality of the knowledge acquired through vicarious learning and, in turn, increases firm performance.

Nevertheless, the positive effect of vicarious learning is limited by the bounded rationality of managers (March and Simon, 1958; Reger and Huff, 1993; Fiegenbaum et al., 1996). Managers can process information only up to a certain level of complexity. As a result, they tend to focus their attention on a limited set of issues and ignore others (Ocasio, 1997; Kabanoff and Brown, 2008). Consequently, the amount of knowledge acquired by vicarious learning will not increase indefinitely with the strategic heterogeneity of competitors. When heterogeneity is very high, not every strategic option will receive attention. If the number of observed strategies is large, managers will be unable to assimilate and process every piece of information. Thus, the marginal contribution of each new strategic combination is lower and the limits of the beneficial effect of strategic heterogeneity are more visible. ${ }^{1}$

\section{Competitive alignment and strategic heterogeneity}

The difficulty of achieving an appropriate degree of alignment increases with the level of strategic heterogeneity among rivals. There are two main reasons for this: 1) limited resources, and 2) incompatibility among strategic options. First, when firms commit resources to different activities, the scarcity of resources might imply trade-offs (Ghemawat, 1991; Porter, 1996). This frequently means that firms have to choose among different actions when they decide their resource commitments. If rivals develop heterogeneous strategies, firms will have to employ their resources in a wide range of activities to protect themselves from a varied array of rivals' actions. A lack of resources prevents firms from developing strategic configurations

\footnotetext{
${ }^{1}$ As an anonymous reviewer suggests, the relationship between strategic heterogeneity and vicarious learning may be curvilinear. For example, it may be possible that, above a certain level of strategic heterogeneity among competitors, firms are not only unable to continue learning vicariously, but are even unable to make sense of what had already been learned (information overload could be a reason). Importantly, this does not affect Hypothesis 1 , given that it only requires that there is an upper limit on vicarious learning.
} 


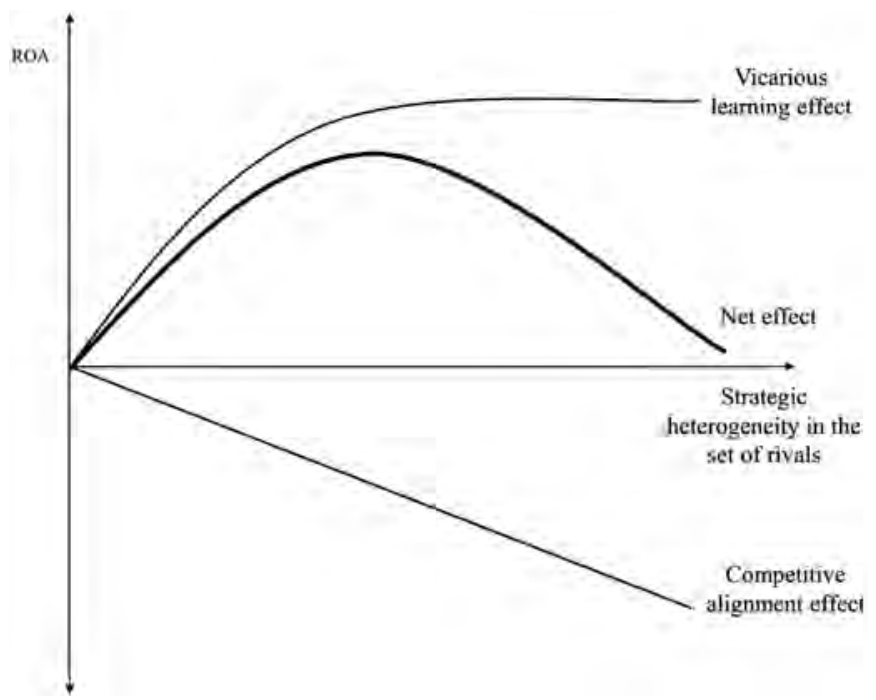

Figure 2. Strategic heterogeneity in the set of rivals, vicarious learning and competitive alignment

that can simultaneously deal with different contingencies. Therefore, in heterogeneous contexts, firms have to decide to which activities they will assign their resources. This increases the likelihood of them being insufficiently protected from the actions that are not covered by the chosen configurations.

Second, even if resources were not scarce, achieving competitive alignment might also be complicated because of incompatibility among strategic activities. Adjusting to some rivals may require actions that are incompatible with the actions necessary to adjust to others. In these circumstances, the firm will be unable to protect itself against every single contingency, even if it has sufficient resources. For instance, a retail bank with a set of rivals pursuing a proximity banking strategy may adapt to them by introducing a high quality service or by increasing its branching network. However, these adaptations may constrain the capability of the bank to adapt to a low-cost or low-service strategy pursued by a different set of rivals. In situations of high heterogeneity, where the probability of incompatibility among strategic positions is greater, adjustment in one direction will inhibit adaptation in others (Barnett, 2008; Barnett and Hansen, 1996; Levinthal and March, 1993).

Both in the case of limited resource availability and in that of incompatibility among strategic options, it is difficult for the firm to achieve a reasonable degree of alignment against each rival, which has a negative effect on performance. Strategic heterogeneity among competitors increases the likelihood of these two situations occurring. Consequently, from the perspective of competitive alignment, strategic heterogeneity among competitors is inversely related to profitability. ${ }^{2}$

\section{Strategic heterogeneity, vicarious learning and competitive alignment}

Figure 2 depicts the predicted effect of strategic heterogeneity on firm performance that results from its partial effects on vicarious learning and competitive alignment. On the one hand, strategic heterogeneity enhances vicarious learning and increases the pool of organizational knowledge. The higher the quantity and quality of organizational knowledge, the more effective the strategic decision-making process and the better the performance of the firm will be. We predict that this effect will have diminishing marginal returns due to the bounded rationality of managers, which restricts the learning capacity of the firm. On the other hand, strategic heterogeneity reduces competitive alignment as a consequence of limited resources and the incompatibility of strategic options. This has a negative effect on firm performance.

As the positive effect (enhanced knowledge) is limited, and the negative effect (reduced competitive alignment) grows monotonically with strategic heterogeneity among competitors, we anticipate that the net effect will show an inverted $U$ shape. Firms operating in a context of very low or very high levels of strategic heterogeneity will perform worse than those that operate in contexts of moderate heterogeneity. ${ }^{3}$

Hypothesis 1: Strategic heterogeneity in the set of rivals has an inverted U-shaped effect on firm performance.

\footnotetext{
${ }^{2}$ It may also be that the costs associated with competitive alignment increase more than proportionally with strategic heterogeneity among competitors if, for instance, strategic complexity accumulates in a multiplicative way. In that case, hypothesis 1 would still hold, as it only requires the costs associated with competitive alignment to be monotonically increasing with strategic heterogeneity among competitors.

${ }^{3}$ We treat vicarious learning and competitive alignment as independent processes. However, there may be interdependences between the two constructs. For instance, vicarious learning may reduce the costs associated with competitive alignment. Note that, for our hypothesis to hold, it suffices that, i) the benefits of vicarious learning are bounded, and ii) the costs associated with competitive alignment are not. As long as any interaction effect does not eliminate the upper bound of vicarious learning or renders competitive alignment costs negligible, our reasoning applies.
} 
This research proposes that the influence of strategic heterogeneity in the set of rivals depends on how long the focal firm has been confronting the same rivals. In our setting, the competitive experience with the same rivals is considered as a source of information and, therefore, only affects vicarious learning. ${ }^{4}$ This means that, when the firm has already confronted its current rivals, it can learn different strategic options not only by directly observing them, but also by retrieving information about past observations of them. We propose that, as a firm accumulates experience from competing with its direct rivals, the need, utility and incentives to vicariously learn from their strategic heterogeneity decreases. As a consequence, the experience accumulated against current rivals discourages the tendency of the firm to learn vicariously, reducing the impact of strategic heterogeneity in the set of rivals on performance.

Organizational memory is a key element in our argument because it is a mechanism by which firms store and retrieve information throughout their competitive history (Huber, 1991). Thanks to organizational memory, firms are able to accumulate information about strategic alternatives in the form of procedures, norms and rules (Huber, 1991; Simon and Lieberman, 2010). In our setting, competitive experience, by involving the observation of rivals over time, increases the volume of information contained in organizational memory about strategic positions of current rivals. Once firms have stored the strategies of their rivals in their memories, they may monitor and consider them less extensively as a source of information. We base this assertion on the three mechanisms suggested by Schwab (2007), information preference, information redundancy and information costs, to explain how, as competitive experience increases, firms tend to use information stored in the organizational memory instead of gathering information through observation.

Information preference refers to the common tendency of firms to use internal rather than external information because internal information is typically more detailed, salient and better understood than external information (Levinthal and March, 1993). A long competitive history allows firms to refine their knowledge about the strategic options employed by their rivals, which would imply that information about rivals stored in the organizational memory is more accurate than information gathered simply through direct observation. So the information that comes from their organizational memory will be reliable and reduce the incentives to learn by directly observing rivals.

Information redundancy takes place when firms obtain the same information from different sources. As we have mentioned, organizational memory and the current observation of competitors can be considered as sources of information. Firms may decide between elaborating knowledge from the information stored in their memories or through observing others (Baum et al., 2000; Bruneel et al., 2010). The strategic options employed by rivals are stored in the organizational memory as firms confront them over time. Therefore, a long competitive history confronting the same rivals results in a more thorough knowledge of their market positions. In situations in which firms maintain stable competitive relationships, it is more than likely that the information acquired through observation will already be known. In this sense, competitive experience makes information that comes from vicarious learning redundant, which reduces the usefulness of observing rivals.

Information costs are a consequence of information search and processing. Vicarious learning requires incurring information costs when scanning the competitive environment, monitoring rivals and making inferences about the information obtained through observation. As a result, vicarious learning involves a cost that stems from gathering and processing external information. One way of reducing information costs is to use information that is already available (Lant and Baum, 1995; Ocasio, 1997). For example, by using information stored in the organizational memory, firms do not need to scan and interpret the competitive environment. Thus, instead of learning vicariously, firms can utilize the knowledge stored in the organizational memory. One way to accumulate information on in the organizational memory is through competitive experience with the same rivals. Therefore, competitive experience replaces vicarious learning.

The three mechanisms proposed by Schwab (2007) provide us with arguments to explain how competitive experience substitutes strategic heterogeneity as a source of learning. The propensity of firms to learn by observation decreases as they acquire competitive experience with the same rivals. As explained above, when external and internal information is redundant - which probably happens when firms have been confronting the same rivals for a long time - these firms rely on information stored in their organizational memory, because it tends to be more reliable and less costly. Thus, competitive experience reduces the tendency of firms to vicariously learn from rivals and favours the application of knowledge from the organizational memory. In doing so, competitive experience reduces the importance of strategic heterogeneity in the set or rivals as a source of information. On the basis of these ideas, we advance a second hypothesis:

Hypothesis 2: The competitive experience accumulated by confronting the same rivals negatively moderates the effect of strategic heterogeneity in the set of rivals on performance.

The proposed effect of our second hypothesis is graphically depicted in Figure 3.

\footnotetext{
${ }^{4}$ We explain the moderating effect of competitive experience focusing exclusively on vicarious learning. While information gathered in the past is accumulated in the organizational memory, making contemporaneous learning less necessary, the competitive alignment granted by a strategic position held in the past cannot be transferred to a new competitive position. Consequently, experience affects vicarious learning, but not competitive alignment. Consistent with this view, the literature on organizational learning has studied experience as a learning source but, as far as we know, the literature has not analyzed the consequences of experience on competitive alignment.
} 


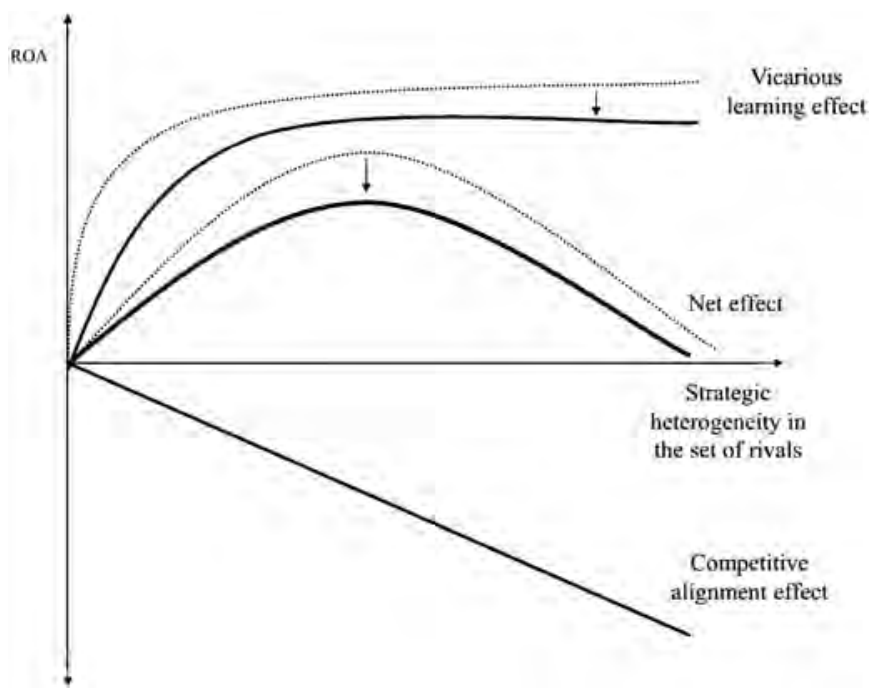

Figure 3. The moderating effect of competitive experience

\section{Empirical analysis}

\section{Research context}

Our research is carried out in the context of the Spanish retail banking sector between 1999 and 2009. This sector includes three kinds of agents: savings banks, commercial banks and credit unions. We include banks whose activities are similar enough to experience comparable environments, enjoy mutual learning opportunities and compete for the same potential customers. The savings bank and commercial bank organizational forms were formally established in the first half of the nineteenth century to cover different activities. Savings banks specialized in retail banking, while commercial banks, in their origins, had a significant wholesale banking orientation. The third kind of agent, the credit union, was established in the early twentieth century to propel financial inclusion and local development of rural areas.

From its inception, the sector was subject to a strict regulation that restricted the activities and geographical scope of financial intermediaries, resulting in different rights and duties for the three types of agents. Geographical restrictions and mandatory investment quotas generated the most important differences. Regarding geographical scope, each bank had its activities restricted to a certain area within the country. At the same time, regulation required investment coefficients on certain activities for each kind of bank. Regulation also prevented some types of agents from offering certain products, which reinforced the differentiation of activities among them. However, in the last quarter of the twentieth century, Spain modified its banking regulatory framework to reduce formal restrictions, increasing the freedom for banking firms to organize their activities. Among other measures, geographical restrictions, investment coefficients and product restrictions were repealed. Each agent was allowed to carry out activities that were previously restricted for them and to expand their geographic scope freely. As a result, the different types of banks became direct competitors in the retail banking sector (Coello, 1994).

During the period analyzed there was a noticeable expansion in the activities of Spanish banking firms. Between 1999 and 2009 the number of branches operated by Spanish banks grew from less than 39,000 to about 44,000. In terms of total assets, this growth was even more pronounced. Total assets multiplied by 3, from less than 1,000 billion euros in 1999 to more than 3,000 billion euros in 2009. There was substantial variation in the scope and size of banks. For instance, in 2009, the two largest banks were Banco Santander (2,945 branches and 416 billion euros assets) and Banco Bilbao Vizcaya Argentaria (3,070 branches and 391 billion euros assets). At the other extreme, there were several dozen small banks that operated only a few branches and much lower total assets.

Consequently, the Spanish retail banking sector is an interesting setting for our analysis for many reasons. First, as in other contexts (see, for example, Hambrick et al., 2005), the elimination of the existing regulation has increased the number of strategic combinations firms can develop and, more generally, the extent of intra-industry heterogeneity (Collis and Noda, 2001). Second, the fact that all the intermediaries are able to operate all over the country has produced a significant process of entries into new markets (Fuentelsaz and Gómez, 2001; Fuentelsaz et al., 2003), increasing the number and variety of rivals that a firm has to confront. In sum, the industry seems an appropriate context in which to study firms' opportunities for learning and their needs of achieving competitive alignment.

\section{Sample and data sources}

Our sample covers the period 1999-2009. The number of firms included in each year fluctuates between 163 and 124 . This fluctuation is explained by several mergers and acquisitions that take place over the period analyzed. 
Importantly, certain firms in the Spanish banking sector do not carry out any important retail banking activities. For instance, investment banks focus on high profile customers and do not offer conventional retail banking services. Also, there are small rural banks that provide their services exclusively to a given community within a limited area. These banks do not properly compete with other retail banks, and there is little or no potential for cross learning. Therefore, they are excluded from the sample. We exclude banks that do not exceed four branches in any of the years because this is associated with extreme geographical specialization and insignificant retail banking activities. ${ }^{5}$ The sample also excludes banks without headquarters in the country because they do not publish detailed information on their activities in the Spanish subsidiary. ${ }^{6}$ In spite of these exclusions, our sample is clearly representative of the Spanish banking sector. For instance, it includes 97.8 percent of the total assets in 2009.

The data used in this study have been collected from different sources. First, we take information on the address of every branch located in Spain from Guia de la Banca, Cooperativas de Crédito y Cajas de Ahorro, which is published yearly by Editorial Maestre Ediban. We use this information to identify direct competitors as those firms that own branches in the same locations. Second, we obtain information on financial statements from yearbooks published by the different trade associations in the sector. ${ }^{7}$ This is the source used to analyze the strategic configurations of banks. Finally, information on market level factors and on other macroeconomic variables is obtained from the Statistical Bulletin of the Bank of Spain and from the National Institute of Statistics (INE).

\section{Variables}

\section{Dependent variable}

Our dependent variable is firm performance. Three different approaches are usually considered to measure firm performance: price-cost margins, market-based measures (e.g., Tobin's q) and accounting-based measures (e.g., ROA) (Scherer and Ross, 1990). Price cost margins are difficult to calculate because of the multiplicity and complexity of products offered in the retail banking market and because banking firms are reluctant to disclose detailed information on the costs and incomes associated with their products. Market-based measures require firms to be listed. In the Spanish banking market, only a few commercial banks were listed during the period analyzed. Therefore, market-based performance measures cannot be computed for the whole sample. Consequently, we use an accounting-based firm performance measure as the dependent variable. We take financial performance, measured as return on assets (ROA), the ratio of profits before taxes over total assets, as the dependent variable. ROA has frequently been used as a financial performance measure when analyzing the banking sector (see, for instance, Barnett et al., 1994; Fuentelsaz et al., 2012; Roberts and Amit, 2003). Each kind of bank was subject to the same accounting requirements, so their financial statements are comparable.

\section{Independent variables}

The main independent variable is strategic heterogeneity in the set of competitors. The first step for constructing this variable is to identify the strategic configuration of each firm in the banking sector. The strategic position of a firm is depicted as a function of its scope and its resource commitments (Cool and Schendel, 1987; Mehra, 1996; Ferguson et al., 2000). Decisions about scope include the choice of market segment. Resource commitment involves the assignment of human, capital and financial factors. In this research, the strategy of each firm is described through seven variables that depict both these dimensions. All of them have been employed in previous research in the banking sector (Zúñiga-Vicente et al., 2004; Fuentelsaz and Gómez, 2006; Prior and Surroca, 2006).

The strategic scope of a given firm is measured through the following five variables:

1. Commercial banking (Commercial loans/Financial investments): This ratio captures the banks' orientation towards commercial banking. This strategic orientation is usually characterized by a high percentage of loans to domestic economies and small and medium-sized firms.

2. Investment banking (Portfolio of securities/Financial investments): This variable determines the extent to which a bank is oriented towards active investments in stock markets.

3. Institutional banking (Transactions with other financial entities and the public sector/Financial investments): This ratio indicates an institutional orientation. Firms that develop this kind of strategy tend to provide financial resources to other financial entities and public institutions.

4. Net position in the financial system (Net position in the financial markets/Total liabilities): This ratio depicts the bank's position in the interbank market. Specifically, it captures the extent to which a bank obtains funds in this market.

\footnotetext{
${ }^{5}$ Some of these organizations (e.g., investment banks) may still be of a substantial size in terms of total assets. However, as they offer their products exclusively to selected customers, or they do not carry out retail banking activities, they are not included in the sample.

${ }^{6}$ International banks that carry out retail banking activities have established headquarters in the country, but many of them do not have an important presence. Therefore, most banks omitted because of insufficient data would also have been excluded because of their lack of retail banking activities (i.e., they do not control at least five branches in any period).

${ }^{7}$ Some information is also offered about international banks without headquarters in Spain, but it is too aggregated to allow a proper analysis.
} 
5. Traditional banking (Saving and deposits accounts of the private sector/Total liabilities): This variable identifies the traditional banking business, based on the accumulation of family savings. These firms get funds through classical financial products.

Similarly, resource commitment is captured through two ratios:

6. Human capital (Personnel expenses/Operating income): This variable captures the importance of human capital.

7. Risk (Net insolvencies/Operating income): This measure tries to approximate the degree of risk that the firm is exposed to. It reflects loans with a low probability of being recovered.

All of these dimensions depict strategic decisions (Zúñiga-Vicente et al., 2004). The commercial, investment and institutional banking variables classify Spanish banking entities according to their capacity to provide financial funds. Net position in the financial system and traditional banking differentiate between two types of banking activities according to how the financial resources are obtained. Finally, human capital shows the extent to which firms commit human resources and risk shows the risk profile of the strategy followed. Each bank is assigned a position in the seven-dimensional strategic space according to its values in the seven strategic variables. ${ }^{8}$ After that, calculating our main explanatory variable requires identifying the relevant group of rivals.

Rivals are identified following a geographical criterion. Previous research has demonstrated that customers hold their accounts and get retail banking services from branches that are located close to their home or their workplace (Radecki, 1998; Simons and Stavins, 1998). This pattern has been found for a wide array of services including credit accounts, consumer deposits, commercial loans, mortgages and small business loans (Cole and Wolken, 1995; Hannan, 1991; Kwast et al., 1997; Sharpe, 1997; Rhoades, 1992). Consequently, there is little (or zero) cross-elasticity of demand among different geographical markets. That is, only firms within the same geographical market are considered as alternatives from the perspective of the customers and are, therefore, direct competitors. Moreover, geographical proximity permits more frequent contacts between rivals, which enhances organizational learning (Hendry and Brown, 2006). Therefore, a geographical definition of markets is also consistent with our theoretical model.

The definition of the market should consider the area within which a customer would look for branches to get retail banking services (de Juan, 2003). We define geographical markets at the ZIP code level. A ZIP code may include several villages in a small area whereas large towns may have several ZIP codes. ZIP codes were initially established to arrange postal services. Therefore, the ZIP code identifies areas that are functionally proximate. Accordingly, the set of rivals is composed of firms that operate at least in one of the ZIP codes in which the focal firm also does. Firms are considered to operate in every market in which they have located any of their branches. It should be noted that our conception of the set of rivals assumes that the group of competitors is specific to each firm in the industry, that is, we consider that every firm in the industry confronts a particular set of rivals.

To measure the level of strategic heterogeneity in the set of rivals of a focal firm, we follow a two-step procedure. First, we calculate the Euclidean distance between each rival and the centroid of the strategic positions of all the direct rivals of the firm.

$$
\text { Strategic Distance }{ }_{j}=\sqrt{\sum_{k=1}^{7}\left(X_{j k}-\bar{X}_{k}\right)^{2}}
$$

where $\mathrm{j}$ refers to the $\mathrm{n}$ rivals with which the focal firm competes, and $\mathrm{k}$ refers to the 7 strategic variables defined above. Let $\bar{X}_{k}$ be the mean value of a strategic variable $\mathrm{k}$ for all of the $\mathrm{n}$ competitors of the focal firm. Correspondingly, the vector $\left(\bar{X}_{1} \ldots \bar{X}_{7}\right)$ identifies the centroid of the strategic space occupied by these rivals. As each firm participates in different geographical markets (defined at the zip code level), each firm also has a different set of rivals with its own strategic centroid.

In the second step, we calculate the mean strategic distance of these competitors.

$$
\text { Strategic Heterogeneity in the Set of Competitors } s_{i}=\frac{\sum_{j=1}^{n}{\text { Strategic } \text { Distance }_{j}}}{n}
$$

where the subscript i refers to the focal firm and the other subscripts have been defined above. A low value of strategic heterogeneity in the set of competitors should be interpreted as indicative that, on average, the rivals of a focal firm occupy similar strategic positions whether or not their positions are similar to the strategic position of the focal firm. High values, on the other hand, imply that the rivals are strategically heterogeneous. According to Hypothesis 1 , both situations should be

\footnotetext{
8 The seven strategic variables are standardized before this calculation.
} 
different in terms of the opportunities for learning and of the difficulties of finding an appropriate strategic positioning. This variable is used to test Hypothesis $1 .^{9}$

Our second theoretical variable is competitive experience. This variable reflects the number of years in which the focal firm has been confronting the same rivals. For each of its current competitors, it is calculated as the number of years out of the last seven in which both firms have competed in at least one zip code. Then, it is averaged among all of its current competitors. We limit this variable to seven years because, after a certain time, the competitive experience effect may disappear (e.g., Barnett and Hansen, 1996). In addition, empirical studies have shown that firms not only learn, but also forget the acquired knowledge (Argote et al., 1990; Darr et al., 1995). In our framework, this means that firms are not always able to recover past information, especially when it was obtained a long time ago.

High values of competitive experience mean that firms have competed for long periods with their current set of competitors. In contrast, low values of competitive experience may result from young firms or from changes in the composition of the set of direct rivals. The variable competitive experience is introduced both as a direct term and as an interaction term with the variable strategic heterogeneity in the set of competitors to explore the moderating effect advanced in Hypothesis 2.

\section{Control variables}

We include three controls at the market level: unemployment, number of rivals and dynamism of the set of rivals. Unemployment describes the unemployment rate in the provinces in which the bank operates. We expect a negative influence of this variable on firm performance. Number captures the number of rivals with which the firm competes. This variable is meant to control for competitive intensity. It is expected that the larger the number of rivals, the more intense the rivalry between them. Finally, dynamism of the set of rivals depicts the change in the market positions of direct competitors. Learning and achieving competitive alignment are easier when rivals maintain their positions over time. In these situations, firms can observe the longterm consequences of the strategies used by their competitors. At the same time, the continuous effort of achieving competitive alignment is reduced due to the stability in the behaviors of rivals. To calculate this variable, we need to determine the strategic variation of each rival as the Euclidean distance between their strategic positions in two consecutive periods.

$$
\text { Strategy } \text { Variation }_{j}=\sqrt{\sum_{j=1}^{n}\left(X_{j k t}-X_{j k t-1}\right)^{2}}
$$

where $X_{j k t}$ is the value of firm $\mathrm{j}$ in strategic variable $\mathrm{k}$ in period $\mathrm{t}$, and $X_{j k t-1}$ is the value of the same variable in the previous year. The variable dynamism of the set of competitors is calculated as the average strategy variation among the $n$ competitors of the focal firm:

$$
\text { Dynamism of the set of competitors } i=\frac{\sum_{j=1}^{n}{\text { Strategy } \text { Variation }_{j}}}{n}
$$

We also include several firm-level controls. Inefficiency, measured as the ratio of operating costs over ordinary margin, and risk, measured as the ratio of total credits over total assets (Carbó et al., 2003). We also control for firm size, $\log$ (total assets), and for the strategic distance of the firm from competitors to take into account the traditional effect of strategic similarity on profitability, calculated as the Euclidean distance between the strategic position of the focal firm and the centroid of the strategic distribution of its set of competitors.

Finally, we must include the direct effect of competitive experience to adequately interpret the moderating effect of the experience that firms accumulate by competing with the same rivals on the link between strategic heterogeneity and performance. By including this variable, we control for the direct influence that a long competitive history confronting the same rivals produces on learning and alignment.

Descriptive statistics and correlations between variables are shown in Table 1.

\section{Model estimation}

We carried out several specification tests to choose the appropriate model. The Breusch-Pagan Lagrange Multiplier test rejects the null hypothesis that the variance of firm-level effects is zero $(X 2=438.17$; $\mathrm{p}$-value $=0.000)$, which is interpreted as evidence of individual effects. The Hausman test indicates the presence of fixed effects $(X 2=85.01$; p-value $=0.00)$. Consequently, we estimate a fixed effects model. Furthermore, to control for contemporary shocks common to all the firms in the sector, such as the economic cycle or regulatory decisions, the model includes annual fixed effects. Consequently, we estimate a two-way fixed effects model. Standard errors are robust to autocorrelation and heteroskedasticity, and residuals are clustered by firm.

\footnotetext{
${ }^{9}$ As illustration, the largest firms in the Spanish retail-banking sector, Banco Santander and Banco Bilbao Bizcaya Argentaria, face medium levels of strategic heterogeneity (1.69 in both cases). The lowest and the highest levels of heterogeneity in the group of rivals are found for Caja de Crédito de Petrel (1. 24) and Caja Campo (2.12), both included in the group of credit unions.
} 
Table 1

Descriptive statistics and correlations

\begin{tabular}{|c|c|c|c|c|c|c|c|c|c|c|}
\hline & 1 & 2 & 3 & 4 & 5 & 6 & 7 & 8 & 9 & 10 \\
\hline Mean & 0.92 & 11.50 & 66.58 & 0.56 & 0.68 & 0.68 & 14.13 & 2.30 & 5.91 & 1.96 \\
\hline S.D. & 2.48 & 4.67 & 36.74 & 0.31 & 0.63 & 0.18 & 1.80 & 1.38 & 0.83 & 0.28 \\
\hline Minimum & -25.21 & 0.00 & 4.00 & 0.16 & 0.00 & 0.00 & 9.73 & 0.38 & 1.00 & 1.24 \\
\hline Maximum & 59.00 & 30.20 & 162 & 1.52 & 12.63 & 0.99 & 19.30 & 13.67 & 7.00 & 2.75 \\
\hline 1. ROA & 1.00 & & & & & & & & & \\
\hline 2. Unemployment & -0.05 & 1.00 & & & & & & & & \\
\hline 3. Number of rivals & -0.06 & -0.01 & 1.00 & & & & & & & \\
\hline 4. Dynamism of the set of rivals & 0.02 & -0.05 & -0.06 & 1.00 & & & & & & \\
\hline 5. Inefficiency & -0.32 & 0.04 & -0.02 & 0.00 & 1.00 & & & & & \\
\hline 6. Risk & 0.18 & 0.09 & -0.09 & 0.10 & -0.16 & 1.00 & & & & \\
\hline 7. Log (assets) & 0.10 & 0.01 & 0.83 & -0.01 & -0.17 & 0.06 & 1.00 & & & \\
\hline 8. Strategic distance of the firm from competitors & -0.29 & -0.08 & -0.16 & 0.00 & 0.25 & -0.43 & -0.31 & 1.00 & & \\
\hline 9. Competitive experience & 0.14 & -0.04 & 0.24 & -0.03 & -0.10 & -0.04 & 0.28 & -0.10 & 1.00 & \\
\hline 10. Strategic heterogeneity in the set of competitors & -0.03 & -0.17 & 0.38 & -0.13 & 0.08 & -0.15 & 0.23 & 0.05 & -0.08 & 1.00 \\
\hline
\end{tabular}

\section{Results}

Table 2 shows our estimations. Column 1 shows the baseline model, which includes the control variables. The baseline model is globally significant, confirming the importance of the controls introduced. Column 2 adds the direct effect of strategic heterogeneity in the set of competitors. This variable is not statistically significant. Column 3 includes the squared effect of strategic heterogeneity in the set of competitors (Hypothesis 1). In this estimation, the direct and squared effects of our main theoretical variable are statistically significant. In addition, the introduction of the squared effect improves the fit of the model, as the Wald test indicates (bottom of the table). Column 4 shows the fully specified model in which strategic heterogeneity in the set of competitors interacts with competitive experience (Hypothesis 2 ). This new estimation shows significant parameters for all the theoretical variables and the fit of the model improves (see Wald test at the bottom of the table).

Table 2

Estimations of the profitability model

\begin{tabular}{|c|c|c|c|c|}
\hline & $(1)$ & $(2)$ & (3) & $(4)$ \\
\hline Unemployment & $\begin{array}{l}-0.0180^{* *} \\
(-2.20)\end{array}$ & $\begin{array}{l}-0.0180^{* *} \\
(-2.23)\end{array}$ & $\begin{array}{l}-0.0161^{* *} \\
(-1.99)\end{array}$ & $\begin{array}{l}-0.0132 \\
(-1.64)\end{array}$ \\
\hline Number & $\begin{array}{l}-0.00312 \\
(-0.90)\end{array}$ & $\begin{array}{l}-0.00308 \\
(-0.86)\end{array}$ & $\begin{array}{l}-0.00437 \\
(-1.22)\end{array}$ & $\begin{array}{l}-0.0101^{* * *} \\
(-2.76)\end{array}$ \\
\hline Dynamism of the set of rivals & $\begin{array}{l}-0.0374 \\
(-0.15)\end{array}$ & $\begin{array}{l}-0.0365 \\
(-0.14)\end{array}$ & $\begin{array}{l}-0.0912 \\
(-0.35)\end{array}$ & $\begin{array}{l}-0.0862 \\
(-0.35)\end{array}$ \\
\hline Inefficiency & $\begin{array}{l}-0.129 \\
(-1.29)\end{array}$ & $\begin{array}{l}-0.129 \\
(-1.28)\end{array}$ & $\begin{array}{l}-0.132 \\
(-1.31)\end{array}$ & $\begin{array}{l}-0.0915 \\
(-0.92)\end{array}$ \\
\hline Risk & $\begin{array}{l}0.199 \\
(0.55)\end{array}$ & $\begin{array}{l}0.199 \\
(0.55)\end{array}$ & $\begin{array}{l}0.225 \\
(0.63)\end{array}$ & $\begin{array}{l}0.194 \\
(0.58)\end{array}$ \\
\hline Log (assets) & $\begin{array}{l}0.0627 \\
(0.27)\end{array}$ & $\begin{array}{l}0.0618 \\
(0.26)\end{array}$ & $\begin{array}{l}0.0466 \\
(0.20)\end{array}$ & $\begin{array}{l}-0.0116 \\
(-0.05)\end{array}$ \\
\hline Strategic distance from competitors & $\begin{array}{l}-0.187^{* *} \\
(-1.96)\end{array}$ & $\begin{array}{l}-0.187^{*} \\
(-1.96)\end{array}$ & $\begin{array}{l}-0.185^{*} \\
(-1.95)\end{array}$ & $\begin{array}{l}-0.196^{* *} \\
(-2.07)\end{array}$ \\
\hline Year effects & Yes*** & Yes ${ }^{* * *}$ & Yes ${ }^{* * *}$ & Yes*** \\
\hline Competitive experience & $\begin{array}{l}0.238^{* * *} \\
(3.35)\end{array}$ & $\begin{array}{l}0.238^{* * *} \\
(3.35)\end{array}$ & $\begin{array}{l}0.228^{* * *} \\
(3.22)\end{array}$ & $\begin{array}{l}4.272^{*} \\
(1.90)\end{array}$ \\
\hline Strategic heterogeneity in the set of competitors & & $\begin{array}{l}-0.00865 \\
(-0.05)\end{array}$ & $\begin{array}{l}3.276^{* *} \\
(2.37)\end{array}$ & $\begin{array}{l}29.96^{* *} \\
(2.16)\end{array}$ \\
\hline Strategic heterogeneity in the set of competitors ${ }^{2}$ & & & $\begin{array}{l}-0.794^{* *} \\
(-2.29)\end{array}$ & $\begin{array}{l}-8.396^{* *} \\
(-2.42)\end{array}$ \\
\hline $\begin{array}{l}\text { Strategic heterogeneity in the set of } \\
\text { competitors X Competitive experience }\end{array}$ & & & & $\begin{array}{l}-4.834^{* *} \\
(-2.10)\end{array}$ \\
\hline $\begin{array}{l}\text { Strategic heterogeneity in the set of } \\
\text { competitors }{ }^{2} \mathrm{X} \text { Competitive experience }\end{array}$ & & & & $\begin{array}{l}1.367^{* *} \\
(2.37)\end{array}$ \\
\hline $\mathrm{N}$ & 1373 & 1373 & 1373 & 1373 \\
\hline Adj. $\mathrm{R}^{2}$ & 0.164 & 0.164 & 0.170 & 0.221 \\
\hline Wald test vs 1 & & 0.00 & $5.87^{* *}$ & $15.06^{* * *}$ \\
\hline Wald test vs 2 & & & $5.25^{* * *}$ & $14.66^{* * *}$ \\
\hline Wald test vs 3 & & & & $11.75^{* * *}$ \\
\hline
\end{tabular}

$t$ statistics in parentheses.

${ }^{*} p<0.10,{ }^{* *} p<0.05,{ }^{* * *} p<0.01$.

Standard errors are robust to heteroskedasticity and autocorrelation. Residuals are clustered by firm.

The models of Table 2 are estimated by a two-way fixed effects model. 


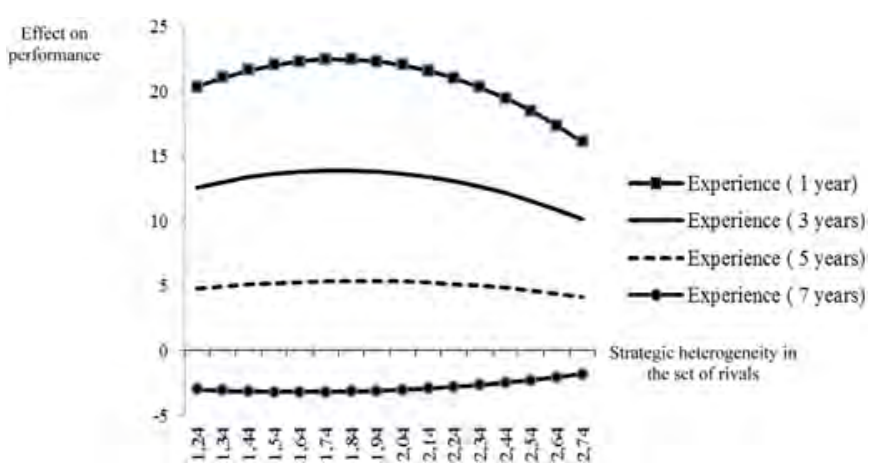

Figure 4. Effect of strategic heterogeneity in the set of rivals for different levels of competitive experience

Hypothesis 1 states that strategic heterogeneity in the set of competitors has an inverted U-shaped effect on firm performance. The parameter of the direct effect in column 3 is positive $(\beta=3.276 ; p<0.05)$ and the parameter of the squared effect is negative $(\beta=-0.794 ; \mathrm{p}<0.05)$. These parameters suggest an inverted U-shaped effect. Nevertheless, for this inverted $\mathrm{U}$ shape to be meaningful in our estimations, the inflection point must belong to the range of values of the variable strategic heterogeneity in the set of competitors observed in the sample. The inflection point is 2.06 , which falls within the range of our sample. Therefore, our estimations support hypothesis 1.

Hypothesis 2 states that competitive experience negatively moderates the effect of strategic heterogeneity in the set of competitors on performance. The parameter of the interaction term between competitive experience and the direct effect of heterogeneity is negative $(\beta=-4.834 ; \mathrm{p}<0.05)$, while the parameter of the interaction term between competitive experience and the squared effect of heterogeneity is positive $(\beta=1.367 ; \mathrm{p}<0.05)$. The combination of these two results generates an effect with an ambiguous interpretation. To understand it, Figure 4 depicts the effect of heterogeneity on performance for representative values of the moderating variable.

The different lines show the effect of strategic heterogeneity in the set of competitors for 1, 3, 5 and 7 years of competitive experience. As the graph shows, the inverted $U$ moves down as competitive experience increases. This confirms that the experience that firms accumulate by competing with the same rivals reduces the effect of the strategic heterogeneity in the set of competitors on performance.

\section{Robustness checks and further analyses}

Table 3 shows the results of several robustness checks and some additional analyses that were performed in order to explore some alternative explanations to our results. ${ }^{10}$ Column 1 analyzes the impact of the financial crisis on our results. In 2008 , an international financial crisis broke out, affecting banking sectors all over the world. ${ }^{11}$ The change in external conditions after the financial crisis modified banking activities as firms adapted to the new situation. Therefore, a position in the strategic space may experience noticeable changes after the crisis. Column 1 shows the estimation of the fully specified model of Table 2 restricted to the period (1999-2007), that is, excluding the years of the crisis. The parameter of the direct term associated with strategic heterogeneity in the set of competitors is positive and significant $(\beta=43.23 ; \mathrm{p}<0.05)$ and the parameter of the squared term is negative and significant $(\beta=-11.20 ; p<0.05)$. The parameters of the interaction terms with competitive experience are also consistent with the main estimations $(\beta=-6.457 ; \mathrm{p}<0.05$ and $\beta=1.696 ; \mathrm{p}<0.05$, respectively). Consequently, our results seem robust to any potential distortions generated by the financial crisis.

Column 2 estimates the full model, but we identify direct rivals defining markets at the provincial level. Therefore, in this analysis, firms that operate in, at least, one of the provinces in which the focal firm develops its activities compose the set of rivals. Note that whereas, in 2009, the last year of our observation window, banks operated in 5,913 different ZIP codes, Spain has only 50 provinces. A province includes several municipalities. As a consequence, identifying rivals at the province level means that a particular firm could be considered as a rival without operating in the same municipality. This new criterion involves an increase in the number of firms that are considered as rivals.

The parameter of the direct term of strategic heterogeneity in the set of competitors is positive and significant $(\beta=1.334$; $\mathrm{p}<0.01)$ and the parameter of the squared term is negative and significant $(\beta=-0.432 ; \mathrm{p}<0.01)$. The parameters of the interaction with competitive experience are $\beta=-0.124$ (n.s) and $\beta=0.064(\mathrm{p}<0.05)$ respectively. These results confirm our first hypothesis about the effect of strategic heterogeneity in the set of competitors. However, the moderating influence of competitive experience is not statistically significant when rivals are identified at the provincial level. This difference may be a

\footnotetext{
${ }^{10}$ Several appreciations of the reviewers showed the necessity of developing these analyses. We are grateful to the reviewers for their helpful comments.

11 Although it is difficult to establish the beginning of the financial crisis, the Bankruptcy of Lehman Brothers (September the 14th of 2008) is usually considered as the starting point in economic media.
} 
Table 3

Robustness checks and further analyses

\begin{tabular}{|c|c|c|c|c|c|c|c|}
\hline & (1) & $(2)$ & (3) & $(4)$ & (5) & (6) & (7) \\
\hline Unemployment & $\begin{array}{l}0.00930 \\
(0.72)\end{array}$ & $\begin{array}{l}-0.0270^{* * *} \\
(-3.11)\end{array}$ & $\begin{array}{l}0.00121 \\
(0.14)\end{array}$ & $\begin{array}{l}0.00118 \\
(0.13)\end{array}$ & $\begin{array}{l}0.000678 \\
(0.08)\end{array}$ & $\begin{array}{l}-0.000341 \\
(-0.04)\end{array}$ & $\begin{array}{l}-0.000591 \\
(-0.07)\end{array}$ \\
\hline Number & $\begin{array}{l}-0.0140^{* * *} \\
(-3.17)\end{array}$ & $\begin{array}{l}-0.00474^{* *} \\
(-2.30)\end{array}$ & $\begin{array}{l}-0.00780^{* * *} \\
(-4.16)\end{array}$ & $\begin{array}{l}-0.00778^{* * *} \\
(-4.16)\end{array}$ & $\begin{array}{l}-0.00841^{\text {*** }} \\
(-4.07)\end{array}$ & $\begin{array}{l}-0.00853^{* * *} \\
(-4.16)\end{array}$ & $\begin{array}{l}-0.00836^{\text {**** }} \\
(-4.02)\end{array}$ \\
\hline Dynamism of the set of rivals & $\begin{array}{l}-0.0478 \\
(-0.16)\end{array}$ & $\begin{array}{l}-0.911^{* *} \\
(-2.32)\end{array}$ & $\begin{array}{l}0.0758 \\
(0.31)\end{array}$ & $\begin{array}{l}0.0751 \\
(0.31)\end{array}$ & $\begin{array}{l}0.0434 \\
(0.17)\end{array}$ & $\begin{array}{l}0.116 \\
(0.47)\end{array}$ & $\begin{array}{l}0.112 \\
(0.46)\end{array}$ \\
\hline Inefficiency & $\begin{array}{l}-0.116 \\
(-0.81)\end{array}$ & $\begin{array}{l}-0.132 \\
(-1.26)\end{array}$ & $\begin{array}{l}-0.158 * \\
(-1.66)\end{array}$ & $\begin{array}{l}-0.159 * \\
(-1.66)\end{array}$ & & & \\
\hline Risk & $\begin{array}{l}-0.190 \\
(-0.51)\end{array}$ & $\begin{array}{l}0.154 \\
(0.43)\end{array}$ & $\begin{array}{l}0.305 \\
(0.87)\end{array}$ & $\begin{array}{l}0.305 \\
(0.87)\end{array}$ & $\begin{array}{l}0.304 \\
(0.88)\end{array}$ & $\begin{array}{l}0.294 \\
(0.86)\end{array}$ & $\begin{array}{l}0.278 \\
(0.82)\end{array}$ \\
\hline Log (assets) & $\begin{array}{l}-0.0783 \\
(-0.32)\end{array}$ & $\begin{array}{l}0.157 \\
(0.61)\end{array}$ & $\begin{array}{l}0.161^{* * *} \\
(3.79)\end{array}$ & $\begin{array}{l}0.161^{* * *} \\
(3.79)\end{array}$ & $\begin{array}{l}0.178^{* * *} \\
(3.84)\end{array}$ & $\begin{array}{l}0.176^{* * * *} \\
(3.88)\end{array}$ & $\begin{array}{l}0.170^{* * * *} \\
(3.67)\end{array}$ \\
\hline Strategic distance from competitors & $\begin{array}{l}-0.221^{* *} \\
(-2.07)\end{array}$ & $\begin{array}{l}-0.205^{* *} \\
(-2.39)\end{array}$ & $\begin{array}{l}-0.0924 \\
(-1.49)\end{array}$ & $\begin{array}{l}-0.0924 \\
(-1.49)\end{array}$ & $\begin{array}{l}-0.106^{*} \\
(-1.70)\end{array}$ & $\begin{array}{l}-0.101^{*} \\
(-1.65)\end{array}$ & $\begin{array}{l}-0.969 \\
(-0.64)\end{array}$ \\
\hline Year effects & Yes $* * *$ & Yes*** & Yes*** & Yes*** & Yes ${ }^{* * *}$ & Yes ${ }^{* * *}$ & Yes*** \\
\hline Competitive experience & $\begin{array}{l}6.236^{*} \\
(1.92)\end{array}$ & $\begin{array}{l}0.000721 \\
(0.01)\end{array}$ & $\begin{array}{l}4.120^{* * * *} \\
(2.91)\end{array}$ & $\begin{array}{l}4.125^{\text {*** }} \\
(2.91)\end{array}$ & $\begin{array}{l}4.445^{* * *} \\
(3.23)\end{array}$ & $\begin{array}{l}4.115^{* * *} \\
(3.19)\end{array}$ & $\begin{array}{l}3.654^{* * *} \\
(2.61)\end{array}$ \\
\hline Strategic heterogeneity in the set of competitors & $\begin{array}{l}43.23^{* *} \\
(2.21)\end{array}$ & $\begin{array}{l}1.334^{* * *} \\
(3.20)\end{array}$ & $\begin{array}{l}26.66^{* * *} \\
(3.00)\end{array}$ & $\begin{array}{l}26.67^{* * *} \\
(3.00)\end{array}$ & $\begin{array}{l}28.45^{* * *} \\
(3.29)\end{array}$ & $\begin{array}{l}25.72^{* * *} \\
(3.19)\end{array}$ & $\begin{array}{l}20.32^{*} \\
(1.89)\end{array}$ \\
\hline Strategic heterogeneity in the set of competitors ${ }^{2}$ & $\begin{array}{l}-11.20^{* *} \\
(-2.38)\end{array}$ & $\begin{array}{l}-0.432^{* * *} \\
(-2.89)\end{array}$ & $\begin{array}{l}-7.282^{* * *} \\
(-3.14)\end{array}$ & $\begin{array}{l}-7.284^{* * *} \\
(-3.14)\end{array}$ & $\begin{array}{l}-7.790^{* * *} \\
(-3.45)\end{array}$ & $\begin{array}{l}-7.075^{* * *} \\
(-3.35)\end{array}$ & $\begin{array}{l}-5.599^{* *} \\
(-2.01)\end{array}$ \\
\hline $\begin{array}{l}\text { Strategic heterogeneity in the set of } \\
\text { competitors X Competitive experience }\end{array}$ & $\begin{array}{l}-6.457^{* *} \\
(-2.02)\end{array}$ & $\begin{array}{l}-0.124 \\
(-1.34)\end{array}$ & $\begin{array}{l}-4.569^{* * *} \\
(-3.08)\end{array}$ & $\begin{array}{l}-4.574^{* * *} \\
(-3.08)\end{array}$ & $\begin{array}{l}-4.938^{* * *} \\
(-3.42)\end{array}$ & $\begin{array}{l}-4.623^{* * *} \\
(-3.41)\end{array}$ & $\begin{array}{l}-4.117^{* * *} \\
(-2.81)\end{array}$ \\
\hline $\begin{array}{l}\text { Strategic heterogeneity in the set of } \\
\text { competitors }^{2} \mathrm{X} \text { Competitive experience }\end{array}$ & $\begin{array}{l}1.696^{* *} \\
(2.21)\end{array}$ & $\begin{array}{l}0.0641^{* *} \\
(2.15)\end{array}$ & $\begin{array}{l}1.248^{* * *} \\
(3.20)\end{array}$ & $\begin{array}{l}1.249^{* * *} \\
(3.21)\end{array}$ & $\begin{array}{l}1.350^{* * *} \\
(3.56)\end{array}$ & $\begin{array}{l}1.277^{* * *} \\
(3.57)\end{array}$ & $\begin{array}{l}1.141^{* * *} \\
(3.00)\end{array}$ \\
\hline Profitabilityt -1 & & & $\begin{array}{l}0.146^{*} \\
(1.83)\end{array}$ & $\begin{array}{l}0.146^{*} \\
(1.83)\end{array}$ & $\begin{array}{l}0.144^{*} \\
(1.87)\end{array}$ & $\begin{array}{l}0.144^{*} \\
(1.92)\end{array}$ & $\begin{array}{l}0.143^{* *} \\
(1.96)\end{array}$ \\
\hline$M \& A$ & & & & $\begin{array}{l}-0.0440 \\
(-0.75)\end{array}$ & $\begin{array}{l}-0.0268 \\
(-0.44)\end{array}$ & $\begin{array}{l}-0.0395 \\
(-0.62)\end{array}$ & $\begin{array}{l}-0.0541 \\
(-0.89)\end{array}$ \\
\hline Average profitability of rivals & & & & & & $\begin{array}{l}0.667^{* * * *} \\
(2.59)\end{array}$ & $\begin{array}{l}0.619^{* *} \\
(2.30)\end{array}$ \\
\hline $\begin{array}{l}\text { Strategic heterogeneity in the set of } \\
\text { competitors X Strategic distance } \\
\text { from competitors }\end{array}$ & & & & & & & $\begin{array}{l}1.005 \\
(0.68)\end{array}$ \\
\hline $\begin{array}{l}\text { Strategic heterogeneity in the set } \\
\text { of competitors }{ }^{2} \mathrm{X} \text { Strategic distance } \\
\text { from competitors }\end{array}$ & & & & & & & $\begin{array}{l}-0.280 \\
(-0.76)\end{array}$ \\
\hline Constant & & & $\begin{array}{l}-25.55^{* * *} \\
(-2.98)\end{array}$ & $\begin{array}{l}-25.58^{* * *} \\
(-2.98)\end{array}$ & $\begin{array}{l}-27.34^{* * *} \\
(-3.28)\end{array}$ & $\begin{array}{l}-24.94^{* * *} \\
(-3.20)\end{array}$ & $\begin{array}{l}-20.01^{*} \\
(-1.87)\end{array}$ \\
\hline $\mathrm{N}$ & 1121 & 1373 & 1373 & 1373 & 1373 & 1373 & 1373 \\
\hline Adj. $\mathrm{R}^{2}$ & 0.228 & 0.170 & & & & & \\
\hline Wald Chi2 & & & $279.86^{* * *}$ & $280.46^{* * *}$ & $282.35^{* * *}$ & $275.69^{* * * *}$ & $308.57^{* * *}$ \\
\hline $\mathrm{AR}(1)$ & & & $-2.70^{* * *}$ & $-2.69^{* * *}$ & $-2.89^{* * *}$ & $-2.97^{* * *}$ & $-2.98^{* * *}$ \\
\hline $\operatorname{AR}(2)$ & & & 1.45 & 1.45 & 1.57 & 1.54 & 1.39 \\
\hline Hansen & & & 0.875 & 0.877 & 0.835 & 0.818 & 0.775 \\
\hline
\end{tabular}

$t$ statistics in parentheses.

${ }^{*} p<0.10,{ }^{* *} p<0.05,{ }^{* * *} p<0.01$.

Standard errors are robust to heteroskedasticity and autocorrelation. Residuals are clustered by firm.

Columns 1 and 2 are estimated by a two-way fixed effects model. Columns 3-7 are estimated by System GMM.

result of a misspecification of the market. Customers in the retail banking sector tend to get retail banking services from offices located close to their living area or their job. This tendency makes it unlikely that a potential customer will consider all the branches in the province as retail banking providers. Consequently, in the Spanish retail banking sector, the provincial level of analysis may be too broad to identify competitors (de Juan, 2003). In other words, identifying rivals at the provincial level may introduce noise into the measure, reducing the efficiency of the estimation and, in turn, the capability of the model to identify the predicted effects.

Column 3 introduces previous performance as a control. Best performers may have access to superior resources and, as a consequence, be able to develop more effective strategies. This fact increases the incentives of firms to achieve competitive alignment with the best performers, given that the lack of alignment with them could be especially harmful. Aligning to the best performers means a higher capacity to respond to any of their moves and, therefore, reduces the probability and severity of their actions (Chen, 1996; Chen et al., 2007). The tendency of firms to prioritize adjustment to the best performers could reduce the complexity of achieving competitive alignment for these firms. Column 3 introduces previous performance to control for this potential bias.

The inclusion of a lagged dependent variable makes our model a dynamic panel data model. Considering fixed effects in a dynamic model can cause problems. Firm-level effects generate correlation between the lagged dependent variable and the 
error term, giving rise to biased estimations (Nickell, 1981). An estimation methodology that can solve this problem is the System GMM (Blundell and Bond, 1998). In this method, fixed effects are removed by first differencing all the variables. Then, the endogeneity of the lagged dependent variable is corrected by instrumenting it with a number of its past observations, both in levels and in differences. For the model to be appropriate, two conditions must hold. First, there must be no second order serial correlation - negative first order serial correlation is provoked by the differentiation of variables, but it is not harmful (Arellano and Bond, 1991). Second, the instruments have to be exogenous (or at least predetermined). These conditions are tested at the bottom of Table 3 with the AR(2) and Hansen tests, respectively (note that subsequent estimations including the lagged dependent variable as a control are also estimated by System GMM). The parameter of the variable profitability $\mathrm{t}_{\mathrm{t}-1}$ is positive and significant $(\beta=0.146 ; \mathrm{p}<0.1)$, indicating some persistence of performance. The results of our main theoretical variables remain qualitatively unchanged.

Column 4 considers the influence of mergers and acquisitions on our results. During the period analyzed, there were several mergers and acquisitions in the Spanish retail banking sector that altered the set of rivals faced by each firm and, therefore, modified the level of heterogeneity in the nearest competitive context. To control for the possible consequences of mergers of acquisitions on vicarious learning and competitive alignment, we introduce the variable $M \& A$ into our analysis. This is a dummy variable that takes the value 1 for firm-year observations involved in a merger or acquisition and 0 otherwise. We expect firms to obtain a temporary negative shock on their profitability in the year in which the merger or acquisition takes place as a result of the assimilation efforts and the distortion on their operations. As Table 3 shows, the parameter of $M \& A$ is not statistically significant. Furthermore, the addition of this variable does not alter our findings.

Column 5 drops the variable inefficiency in order to check the robustness of our results. The variable inefficiency may well be considered as another outcome of the activities of the firm, rather than as a control variable. The elimination of this variable does not alter our results significantly.

Column 6 includes the average profitability of direct rivals as a control. Firms facing high performers may learn more efficient strategic options than firms facing low performers. We control for the average profitability of rivals to consider the potential effects that the success of observed rivals may have on the vicarious learning process. The parameter of the term associated with average profitability of rivals is positive and significant $(\beta=0.667 ; p<0.01)$, which is consistent with this observation. The inclusion of this control variable maintains the effect of our main theoretical variables qualitatively unchanged. $^{12}$

Finally, column 7 analyzes the potential interactive nature between the traditional perspective to examine heterogeneity and the approach that is proposed in this research. In other words, it explores whether the effect of strategic heterogeneity in the set of competitors varies according to the strategic position of the focal firm in relation to its rivals (strategic distance from competitors). Our contention is that firms that occupy similar positions to their rivals benefit more from strategic heterogeneity among them. First, the observation of similar rivals offers information about suitable reactions to opportunities and threats that directly concern the focal firm (Baum et al., 2000; Lieberman and Asaba, 2006). Second, a particular attacker may be hesitant to target a similar rival because it has the necessary capability to effectively retaliate (Chen, 1996; Chen et al., 2007). This means that strategic similarity involves a certain degree of competitive alignment. As a consequence, when firms try to align with the strategic position of similar rivals, they need to carry out fewer internal changes. This fact reduces the resources and efforts employed to achieve competitive alignment, as well as the complexity that stems from adaptation to the set of rivals. Therefore, strategic proximity should improve the capacity of firms to learn from and align with a heterogeneous group of rivals, that is, it should positively moderate the effect that comes from strategic heterogeneity among competitors. ${ }^{13}$

The parameter of the interaction term associated with strategic heterogeneity in the set of competitors and strategic distance from competitors is positive and non-significant $(\beta=1.005 ; n . s)$ and the parameter of the interaction term of strategic heterogeneity in the set of competitors2 and strategic distance from competitors is negative and non-significant $(\beta=-0.280$; n.s). Therefore, we do not find empirical evidence of interactive effects between the traditional perspective to analyze heterogeneity and the strategic heterogeneity in the set of rivals. However, it is noteworthy that the lack of statistical evidence might be the result of the complexity of our model (Aiken and West, 1991). We elaborate on this point in the following section.

\section{Discussion}

In this paper, we analyze the effect of strategic heterogeneity on firm performance by taking a new perspective. We study the consequences of varying levels of heterogeneity in the set of competitors, instead of examining strategic similarity (or

\footnotetext{
${ }^{12}$ As an additional analysis, we replicated our estimations considering the strategic heterogeneity of only the rivals whose profitability is above the annual average of the sector. In these results, we find support for the curvilinear effect of strategic heterogeneity in the set of competitors, but we cannot confirm the moderating effect of competitive experience. This change may result from a misspecification of learning opportunities. Firms learn not only from success, but also from the failures (or near failures) of other firms (Ingram and Baum, 1997; Haunschild and Sullivan, 2002; Kim and Miner, 2007). Consequently, the exclusion of low performers may result in less efficient estimations and lower statistical significance.

${ }^{13}$ To explore the complementary effect of the two perspectives to heterogeneity, we focus on analyzing how strategic distance moderates the effect of strategic heterogeneity among rivals. We consider that this theoretical approach has a more natural fit for the objective of our research, which is to extend the knowledge about the heterogeneity in the set of rivals. Given that vicarious learning and competitive alignment are the mechanisms that help to explain the consequences of heterogeneity among competitors, we explain the moderating influence of strategic distance through these mechanisms.
} 
divergence) between a focal firm and its competitors (Caves and Porter, 1977; McGee and Thomas, 1992; Peteraf, 1993). We analyze how strategic heterogeneity among competitors affects firm performance through two mechanisms: vicarious learning and competitive alignment. Both mechanisms are directly related to our conception of heterogeneity, given that strategic diversity in the set of competitors influences the strategic options from which the firm can learn and the strategic options to which it has to adapt to compete. In addition, we argue that, as firms accumulate experience by competing with the same rivals, the impact of strategic heterogeneity among competitors on performance changes. We explain the moderating influence of competitive experience through information preference, information redundancy and information costs (Schwab, 2007). These mechanisms suggest that experience with the same rivals is a substitute for observation as a source of learning.

The theoretical model receives empirical support. In the case of strategic heterogeneity in the set of competitors, we confirm the predicted inverted U-shaped effect on firm performance. This means that firms that operate in a context with low or high levels of strategic heterogeneity will perform worse than firms that operate in a context with a moderate level of heterogeneity. This pattern is consistent with the two main mechanisms of our theoretical model. First, heterogeneity in the set of competitors enhances organizational learning, but only within the limits imposed by the bounded rationality of managers. Second, heterogeneity among competitors reduces competitive alignment as a consequence of limited resources and of the incompatibility of strategic options.

These results resemble the empirical evidence that employs the traditional approach to examine heterogeneity, at least to a certain extent. Some papers in this literature conclude that the optimum market positions of firms are those that find a balance between similarity and divergence in relation to rivals (Deephouse, 1999; McNamara et al., 2003; Phillips and Zuckerman, 2001; Porac et al., 1989). In the same line, we find that the ideal competitive setting is one in which firms confront a moderately heterogeneous set of competitors. This suggests that a medium level of heterogeneity could provide the best results not only when heterogeneity is simultaneously analyzed in terms of competition and legitimation (Deephouse, 1999), but also when vicarious learning and competitive alignment are the mechanisms employed to explain the consequences of firm heterogeneity. Consequently, it seems that our approach to studying strategic heterogeneity provides additional empirical evidence about the advantages of a moderate level of strategic diversity.

In the case of competitive experience, our findings suggest a complex moderating relationship. However, for the range of values observed in our sample, we confirm that competitive experience negatively moderates the impact of heterogeneity in the set of rivals on firm performance. This means that the effect of heterogeneity dissipates as firms accumulate experience confronting the same rivals. The dilution of the influence of heterogeneity appears to be due to a substitution effect between organizational memory and observation which, as our results suggest, act as alternative sources of learning.

As repeated competitive interactions allow firms to accumulate enough information about rivals, information preference, information redundancy and information costs provide incentives to use the knowledge in the organizational memory, rather than relying on observation. This finding may have important implications for the organizational learning literature that focuses on determining the tendency of firms to learn from internal or external sources of information (Bresman, 2010; Haas and Hansen, 2005; Schwab, 2007; He and Wong, 2004). The fact that competitive experience replaces heterogeneity in the set of rivals as a source of learning shows the preference of the firm for using internal information. Once competitive experience provides the required information about the market positions of rivals, firms rely on it instead of collecting new information from the environment.

Overall, our findings deepen our understanding of intra-industry heterogeneity, which is an important topic in the strategic management field (Barney, 1991; Hatten and Schendel 1977; Rumelt, 1984; Peteraf, 1993). The classical approach to the concept focuses on heterogeneity between the focal firm and its rivals. However, to our knowledge, there are no papers analyzing the implications of heterogeneity among competitors. From this perspective, we can introduce new mechanisms to explore the influence of intra-industry heterogeneity on the performance of industry participants. Instead of using arguments based on competition, legitimacy and collusion, we focus on vicarious learning and competitive alignment. We hope that this new perspective of analysis and the use of new mechanisms to explain the consequences of intra-industry heterogeneity will help to improve our understanding of firm performance.

Finally, it is important to stress that despite the plausibility of an interaction between the traditional approach and the new perspective our analyses do not detect any complementarity between the two perspectives. Therefore, the two perspectives seem to be independent. But, even if this were the case, our main results reveal that the addition of the variables capturing the new perspective are relevant and do not affect the significance of the traditional approach.

\section{Managerial implications}

Our findings have important implications for managers. First, our research shows a new factor that managers should take into account when they analyze their set of rivals: the strategic differences among them. Our results imply that managers should not only pay attention to their strategic positioning in relation to their competitors; they should also consider the degree of heterogeneity in the set of rivals, given that it conditions vicarious learning and competitive alignment. Therefore, we recommend managers to take both perspectives into consideration when formulating their competitive strategy.

Second, our research shows that the attractiveness of a given competitive context depends both on the degree of strategic heterogeneity among competitors and the experience accumulated against them. From the perspective of strategic heterogeneity competitive environments characterized by moderate levels of strategic heterogeneity among competitors provide 
the best balance between learning opportunities and alignment costs. If strategic heterogeneity in the new market is too low, managers will easily achieve competitive alignment, but they will miss the opportunity to learn different strategies, increasing the risk of myopic learning processes and competence traps (Levinthal and March, 1993). If, on the contrary, strategic heterogeneity is too high managers will experience difficulties both to correctly align against rivals and to interpret external information. Consequently, this seems to be the worst scenario. Importantly, these scenarios are heavily influenced by competitive experience. It is important to note that, as firms accumulate experience against their direct competitors, this relationship almost disappears, reducing the importance of the strategic heterogeneity among them. Consequently, when a firm faces rivals with which it shares a long competitive history, their strategic heterogeneity should not be a prime concern.

Third, our findings are informative for entry strategies. As our results show, the effect of strategic heterogeneity among competitors is higher when firms have low, or no, competitive experience with rivals. Consequently, a new firm, or an established firm initiating activities in a new industry, is especially sensitive to the mechanisms described in our model. That is, in addition to paying attention to its strategic distance from its new competitors (Caves and Porter, 1977; Deephouse, 1999), this firm should also be especially attentive to the strategic heterogeneity among rivals, because its lack of competitive experience maximizes the impact of this dimension of strategic heterogeneity. Importantly, this influence is relevant only for inexperienced firms. Our results suggest that, after the firm accumulates competitive experience, this dimension of strategic heterogeneity becomes much less important and the firm should mainly focus on its strategic positioning in relation to these rivals.

\section{Limitations and future research}

It is worth noting some limitations of this research. First, although we theorize in terms of vicarious learning and competitive alignment, we do not measure them. Instead, we take an indirect approach, inferring their influence through their final effect on firm performance. This is a usual procedure when a theoretical relationship is first identified. However, to consolidate the model presented in this article, direct tests of these mechanisms would be necessary. As it is difficult to objectively measure these mechanisms, a suitable approach would be the use of questionnaires. Top managers, as well as middle managers, could be questioned about their perceptions on the ease with which they obtain useful information from their rivals, as well as the extent to which they feel protected against attacks from their competitors. Comparing these perceptions across different levels of strategic heterogeneity may clarify the relationship between strategic heterogeneity among competitors and these constructs, and corroborate the assumptions of this model.

Second, our analysis of the potential complementarity between the strategic distance from competitors and the strategic heterogeneity among these competitors did not detect statistically significant effects, though the theoretical mechanisms at play were sound. This result has to be interpreted with some caution. Aiken and West $(1991,93)$ highlight that even for moderate correlation levels among variables their interaction terms may be highly instable. Furthermore, they point out that a "central issue in testing complex regression equations is that the lower order effects and the interactions are not typically independent" and "...the variance that is shared by terms in the equation could potentially be apportioned to the higher and lower order effects in several different ways" (Aiken and West, 1991, 101-102). That is, the lack of statistical evidence in our analyses may well be the result of the statistical complexities of testing interactions in such a context. Therefore, future research should replicate this analysis in different sectors to further study the complementary nature of the two perspectives. If there were some form of complementarity between the two constructs, its identification may further clarify the influence of strategic heterogeneity on firm performance.

\section{Acknowledgements}

This research was supported by the Spanish Ministry of Science and Technology (project ECO2011-22947), the Diputación General de Aragón (S09/PM062) and the Universidad de La Rioja (EGI11/29). Raquel Orcos acknowledges financial aid from "Programa Europa XXI-CAI", and the hospitality of the University of Warwick. We are grateful to Andy Lockett, Simon Bell, Gianvito Lanzolla, Lucio Fuentelsaz and Juan Pablo Maícas for helpful comments.

\section{References}

Aiken, L.S., West, S.G., 1991. Multiple Regression: Testing and Interpreting Interactions. Sage, Newbury Park, CA.

Aldrich, H.E., Fiol, C.M., 1994. Fools rush in? The institutional context of industry creation. Academy of Management Review 19 (4), 645-670.

Arellano, M., Bond, S., 1991. Some tests of specification for panel data: Monte Carlo evidence and an application to employment equations. Review of Economic Studies 58, 277-297.

Argote, L., Beckman, S., Epple, D., 1990. The persistence and transfer of learning in industrial settings. Management Science 36 (2), $140-154$.

Argote, L., Miron-Spektor, E., 2011. Organizational learning: from experience to knowledge. Organization Science 5, $1123-1137$.

Ashforth, B.E., Gibbs, B.W., 1990. The double-edge of organizational legitimation. Organization Science 1 (2), $177-194$.

Audia, P.G., Kurkoski, J., 2012. An ecological analysis of competition among U.S. communities. Industrial and Corporate Change 21 (1), $187-215$.

Barnett, W.P., Hansen, M.T., 1996. The red queen in organizational evolution. Strategic Management Journal 17 (Special Issue Summer), 139-157.

Barnett, W.P., Greve, H.R., Park, D.Y., 1994. An evolutionary model of organizational performance. Strategic Management Journal 15 (Special Issue), $11-28$.

Barnett, W.P., 2008. The Red Queen Among Organizations: How Competitiveness Evolves. Princeton University Press.

Barney, J.B., 1991. Firm resources and sustained competitive advantage. Journal of Management 17, 99-120.

Baum, J.A.C., Mezias, S.J., 1992. Localized competition and organizational failure in the Manhattan hotel industry, 1898-1990. Administrative Science Quarterly 37 (4), 580-604. 
Baum, J.A.C., Li, S.X., Usher, J.M., 2000. Making the next move: how experiential and vicarious learning shape the locations of chains' acquisitions. Administrative Science Quarterly 45, 766-801.

Bikhchandani, S., Hirshleifer, D., Welch, I., 1998. Learning from the behavior of others: conformity, fads and informal cascades. Journal of Economic Perspectives $12,151-170$.

Blundell, R.W., Bond, S.R., 1998. Initial conditions and moment restrictions in dynamic panel data models. Journal of Econometrics 87, 115-143. Bresman, H., 2010. External learning activities and team performance: a multi-method field study. Organization Science 21 (1), $81-96$.

Bruneel, J., Yli-Renko, H., Clarysse, B., 2010. Learning from experience and learning from others: how congenital and interorganizational learning substitute for experiential learning in young firm internationalization. Strategic Entrepreneurship Journal 4 (2), $164-182$.

Bourgeois III, L.J., 1980. Strategy and environment: a conceptual integration. Academy of Management Review 5 (1), $25-39$.

Carbó, S., López, R., Rodríguez, F., 2003. Medición de la competencia en mercados bancarios regionales. Revista de Economía Aplicada 32 (11), 5-33.

Caves, R., Porter, M., 1977. From entry barriers to mobility barriers, Quarterly Journal of Economics 91 (2), $241-261$.

Chen, M., Hambrick, D.C., 1995. Speed, stealth, and selective attack. How small firms differ from large firms in competitive behaviour. Academy of Management Journal 38, 453-482.

Chen, M., 1996. Competitor analysis and interfirm rivalry: toward a theoretical integration. Academy of Management Review 21 (1), $100-104$.

Chen, M.J., Su, K.H., Tsai, W., 2007. Competitive tension: the awareness-motivation-capability perspective. Academy of Management Journal 50, $101-118$.

Coello, J., 1994. Son las cajas y los bancos estratégicamente equivalentes? Investigaciones Económicas 18 (2), $313-332$.

Cole, R.A., Wolken, J.D., 1995. Financial services used by small businesses: evidence from the 1993 national survey of small business finances. Federal Reserve Bulletin 81, 629-667.

Collis, D.J., Noda, T., 2001. The evolution of intra-industry firm heterogeneity: insights from a process study. Academy of Management Journal 444, 897-925.

Cool, K.O., Dierickx, I., 1993. Rivalry, strategic groups, and firm profitability. Strategic Management Journal 14 (1), $47-59$.

Cool, K.O., Schendel, D.E., 1987. Strategic group formation and performance: the case of the U.S. pharmaceutical industry, 1963-1982. Management Science 33 (9), 1102-1124.

Darr, E., Argote, L., Epple, D., 1995. The acquisition, transfer and depreciation of knowledge in service organizations: productivity in franchises. Management Science 41 (11), 1750-1762.

Deephouse, D.L., 1999. To be different, or to be the same? It's a question (and theory) of strategic balance. Strategic Management Journal 20 (2), 147-166.

DiMaggio, P.J., Powell, W.W., 1983. The iron cage revisited: institutional isomorphism and collective rationality in organizational fields. American Sociological Review 48 (2), 147-160.

Ferguson, T.D., Deephouse, D.D., Ferguson, W.L., 2000. Do strategic groups differ in reputation? Strategic Management Journal 21 (12), $1195-1214$.

Fiegenbaum, A., Hart, S., Schendel, D., 1996. Strategic reference point theory. Strategic Management Journal 17 (3), $219-235$.

Fiegenbaum, A., Thomas, H., 1990. Strategic groups and performance: the U.S. insurance industry, 1970-84. Strategic Management Journal 11 (3), 197-215.

Filatotchev, I., Nakajima, C., 2010. Internal and external corporate governance: an interface between an organization and its environment. British Journal of Management 21 (3), 591-606.

Fuentelsaz, L., Gómez, J., 2001. Liberalización y estrategia competitiva: La expansión de las cajas de ahorro. Cuadernos de Información Económica 164, $74-84$.

Fuentelsaz, L., Gómez, J., 2006. Multipoint competition, strategic similarity and entry to a geographic markets. Strategic Management Journal 27 (5), $447-449$.

Fuentelsaz, L., Gómez, J., Polo, Y., 2003. La evolución de la red de oficinas de Ibercaja. 1980-2001. Cuadernos Aragoneses de Economía 13 (1), 187-198.

Fuentelsaz, L., Gómez, J., Palomas, S., 2012. Production technologies and financial performance: the effect of uneven diffusion among competitors. Research Policy 41 (2), 401-413.

Ghemawat, P., 1991. Commitment: the Dynamic of Strategy. The Free Press, New York.

Gimeno, J., Woo, C., 1996. Hypercompetition in a multimarket environment: the role of strategic similarity and multimarket contact in competitive deescalation. Organization Science 7 (3), 322-341.

Greve, H., 2000. Market niche entry decisions: competition, learning and strategy in Tokyo banking, 1894-1936. Academy of Management Journal 43 (5), $816-836$.

Hambrick, D.C., Finkelstein, S., Cho, T.S., Jackson, E.M., 2005. Isomorphism in reverse. Institutional theory as an explanation for recent increases in intraindustry heterogeneity and managerial discretion. Research in Organizational Behaviour 26, 307-350.

Hannan, T.H., 1991. Bank commercial loan markets and the role of market structure: evidence from the surveys of commercial lending. Journal of Banking and Finance 15 (1), 133-149.

Hannan, M.T., Freeman, J., 1977. The population ecology of organizations. American Journal of Sociology 82 (5), 929-964.

Hannan, M.T., Freeman, J., 1989. Organizational Ecology. Harvard University Press, Cambridge.

Haas, M.R., Hansen, M.T., 2005. When using knowledge can hurt performance: the value of organizational capabilities in a management consulting company. Strategic Management Journal 26 (1), 1-24.

Hatten, K.J., Schendel, D.E., 1977. Heterogeneity within an industry: firm conduct in the US brewing industry, 1952-71. The Journal of Industrial Economics 26 (2), 111-128.

Haunschild, P.R., Sullivan, B.N., 2002. Learning from complexity: effects of prior accidents and incidents on airlines' learning. Administrative Science Quarterly 47 (4), 609-643.

He, Z.-L., Wong, P.-K., 2004. Exploration vs. exploitation: an empirical test of the ambidexterity hypothesis. Organization Science 15, 481-494.

Hendry, C., Brown, J., 2006. Organizational networking in UK biotechnology clusters. British Journal of Management 17 (1), $55-73$.

Huber, G.P., 1991. Organizational learning: the contributing processes and the literature. Organizational Science 2 (1), $88-115$.

Ingram, P., Baum, J., 1997. Opportunity and constraint: organizations' learning from the operating and competitive experience of industries. Strategic Management Journal 18 (Summer Special Issue), 75-98.

Jaworski, B., Kohli, A., 1993. Market orientation. Antecedents and consequences. Journal of Marketing 57, 53-70.

de Juan, R., 2003. The independent submarkets model: an application to the Spanish retail banking market. International Journal of Industrial Organization 21, 1461-1487.

Kabanoff, B., Brown, S., 2008. Knowledge structures of prospectors, analyzers, and defenders: content, structure, stability, and performance. Strategic Management Journal 29 (2), 149-171.

Kwast, M.L., Starr-McCluer, M., Wolken, J.D., 1997. Market definition and the analysis of antitrust in banking. Antitrust Bulletin 42, $973-995$.

Kim, J.-Y., Miner, A., 2007. Vicarious learning from the failures and near failures of others: evidence from the U.S. commercial banking industry. Academy of Management Journal 50 (3), 687-714.

Lant, T.K., Baum, J.A.C., 1995. Cognitive sources of socially constructed competitive groups. In: Scott, W.R., Christensen, S. (Eds.), The Institutional Construction of Organizations. Sage, Thousand Oaks, CA, pp. 15-38.

Levinthal, D.A., March, J.G., 1993. The myopia of learning. Strategic Management Journal 14 (Special Issue Winter), $95-112$.

Lieberman, M., Asaba, S., 2006. Why do firms imitate each other? Academy of Management Review 3 (2), 366 -385.

March, J.C., Simon, H.A., 1958. Organizations. Wiley, New York.

McGee, J., Thomas, H., 1992. Strategic groups and ultra-industry competition. International Review of Strategic Management 3, 77-98.

McNamara, G., Deephouse, D.L., Luce, R.A., 2003. Competitive positioning within and across a strategic group structure: the performance of core, secondary, and solitary firms. Strategic Management Journal 24 (2), 161-181.

Mehra, A., 1996. Resource and market based determinants of performance in the U.S. banking industry. Strategic Management Journal 17 (4), 307-322.

Meyer, J.W., Rowan, B., 1977. Institutionalized organizations: formal structure as myth and ceremony. American Journal of Sociology $83,340-363$. 
Miller, D., 1992. Environmental fit versus internal Fit. Organization Science 3 (2), 159-178.

Miller, D., Chen, M., 1995. Nonconformity in competitive repertoires. In: Moore, D. (Ed.), Academy of Management Best Papers Proceedings, pp. $256-260$.

Nickell, S.J., 1981. Biases in dynamic models with fixed effects. Econometrica 49, 1417-1426.

Ocasio, W., 1997. Towards an attention-based view of the firm. Strategic Management Journal 18 (Summer Special Issue), 187-206.

Peteraf, M.A., 1993. Intra-industry structure and the response toward rivals. Managerial and Decision Economics 14 (6), 519-528.

Peteraf, M., Shanley, M., 1997. Getting to know you: a theory of strategic group identity. Strategic Management Journal 18 (Summer Special Issue), $165-186$.

Phillips, D.J., Zuckerman, E.W., 2001. Middle-status conformity: theoretical restatement and empirical demonstration in two markets. American Journal of Sociology 107 (2), 379-429.

Porac, J., Thomas, H., Baden-Fuller, C., 1989. Competitive groups as cognitive communities: the case of Scottish knitwear manufacturers. Journal of Management Studies 26 (4), 397-416.

Porter, M.E., 1979. The structure within industries and companies' performance. Review of Economics and Statistics 61 (2), 214-227.

Porter, M.E., 1980. Competitive Strategy. Free Press, New York.

Porter, M., 1991. Towards a dynamic theory of strategy. Strategic Management Journal 12 (Winter Special Issue), 95-117.

Porter, M.E., 1996. What Is Strategy? Harvard Business Review (November-December).

Prior, D., Surroca, J., 2006. Strategic groups based on marginal rates: an application to the Spanish banking industry. European Journal of Operational Research 170 (1), 293-314.

Radecki, L.J., 1998. The expanding geographic reach of retail banking markets. Federal Reserve Bank of New York Economic Policy Review 4 (2), 15-34.

Reger, R.K., Huff, A.S., 1993. Strategic groups: a cognitive perspective. Strategic Management Journal 14 (2), $103-123$.

Rhoades, S.A., 1992. Evidence on the size of banking markets from mortgage loan rates in twenty cities. Staff Study, Board of Governors of the Federal Reserve System 162.

Roberts, R.W., Amit, R., 2003. The dynamics of innovative activity and competitive advantage: the case of Australian retail banking, 1981 to 1995. Organization Science 14 (2), 107-122.

Rumelt, R.P., 1984. Towards a strategic theory of the firm. In: Lamb, R.B. (Ed.), Competitive Strategic Management. Prentice-Hall, Englewood Cliffs, N.J, pp. $556-570$.

Scherer, F.M., Ross, D., 1990. Industrial Market Structure and Economic Performance. Houghton Mifflin Company, Boston, MA.

Schwab, A., 2007. Incremental organizational learning from multilevel information sources: evidence for cross-level interactions. Organization Science 18 (2), 233-251.

Sharpe, S.A., 1997. The effect of consumer switching costs on prices: a theory and its application to the bank deposit market. Review of Industrial Organization 12, 79-94.

Siggelkow, N., 2001. Change in the presence of fit: the rise, the fall, and the renaissance of Liz Claiborne. Academy of Management Journal 44 (4), $838-857$.

Simon, D.H., Lieberman, M.B., 2010. Internal and external influences on adoption decisions in multi-unit firms: the moderating effect of experience. Strategic Organization 8 (2), 132-154.

Simons, K., Stavins, J., 1998. Has antitrust policy in banking become obsolete? New England Economic Review, Federal Reserve Bank of Boston, March-April $13-26$.

Suchman, M.C., 1995. Managing legitimacy: strategic and institutional approaches. Academy of Management Review 20 (3), 571-610.

Venkatraman, N., Camillus, J.C., 1984. Exploring the concept of 'fit' in strategic management. Academy of Management Review 9 (3), 513-525.

Vermeulen, F., Barkema, H., 2001. Learning through acquisitions. Academy of Management Journal 44 (3), 457-476.

Zajac, E.J., Kraatz, M.S., Bresser, R.K.F., 2000. Modeling the dynamics of strategic alignment: a normative approach to strategic change. Strategic Management Journal 21, 429-453.

Zúñiga-Vicente, J.A., Fuente-Sabate, J.M., Rodriguez-Puerta, J., 2004. A study of industry evolution in the face of major environmental disturbances: group and firm strategic behaviour of Spanish banks, 1983-1997. British Journal of Management 153 (3), 219-245.

\section{Biographies}

Jaime Gómez is an Associate Professor at Universidad de La Rioja (Spain). His research interests focus on first mover advantages, multimarket competition, the diffusion of innovations and the study of intra-industry heterogeneity. His articles have appeared in Journal of Economics and Management Strategy, Strategic Management Journal, Research Policy and Omega, among others. E-mail: jaime.gomez@unirioja.es

Raquel Orcos received her Ph.D. at Universidad de Zaragoza (Spain), and she is an Assistant Professor at Universidad Pública deNavarra. Her primary research interest is the analysis of intra-industry heterogeneity. She analyzes the topic using different theoretical perspectives, such as population ecology, organizational learning, strategic groups and multimarket contact. E-mail: raquel.orcos@unavarra.es

Sergio Palomas is an Assistant Professor at Universidad de Zaragoza (Spain), from which he received his Ph.D. His research interests focus on the diffusion of innovations, technology management, and the strategic behavior of organizations. His research has appeared in Research Policy and Journal of Evolutionary Economics, among others. E-mail: spalomas@unizar.es 